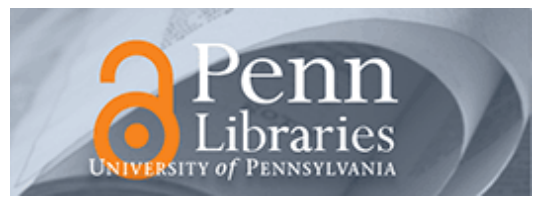

University of Pennsylvania

ScholarlyCommons

Finance Papers

Wharton Faculty Research

4-2001

\title{
Fiscal Policies in Open Cities With Firms and Households
}

Andrew F. Haughwout

Robert P. Inman

University of Pennsylvania

Follow this and additional works at: https://repository.upenn.edu/fnce_papers

Part of the Economics Commons, and the Finance and Financial Management Commons

\section{Recommended Citation}

Haughwout, A. F., \& Inman, R. P. (2001). Fiscal Policies in Open Cities With Firms and Households.

Regional Science and Urban Economics, 31 (2-3), 147-180. http://dx.doi.org/10.1016/

S0166-0462(00)00059-4

This paper is posted at ScholarlyCommons. https://repository.upenn.edu/fnce_papers/195

For more information, please contact repository@pobox.upenn.edu. 


\title{
Fiscal Policies in Open Cities With Firms and Households
}

\begin{abstract}
This paper provides an equilibrium numerical model of an open city economy with mobile firms and resident workers. Given household preferences and firm technologies and an exogenous configuration of city tax rates and national grants and fiscal mandates, the model calculates equilibrium values for aggregate city economic activity, factor prices, and finally, local tax bases, revenues, and public goods provision. The model is calibrated to the Philadelphia economy for Fiscal Year 1998. We then explore the economic and fiscal consequences of raising city tax rates and the city's ability to finance rising local welfare payments. We find the city to be incapable of bearing significant increases in local responsibility for welfare transfers.
\end{abstract}

Keywords

fiscal policy, cities, federalism

Disciplines

Economics | Finance and Financial Management 


\title{
NBER WORKING PAPER SERIES
}

\section{FISCAL POLICIES IN OPEN CITIES \\ WITH FIRMS AND HOUSEHOLDS}

\author{
Andrew Haughwout \\ Robert P. Inman \\ Working Paper 7823 \\ http://www.nber.org/papers/w7823
}

\section{NATIONAL BUREAU OF ECONOMIC RESEARCH \\ 1050 Massachusetts Avenue \\ Cambridge, MA 02138}

August 2000

The authors wish to thank the National Science Foundation for funding and John Quigley, Konrad Stahl, and participants at the ZEW Conference on Fiscal Federalism (University of Mannheim, June, 1999) for comments on an earlier version of this work. The results and conclusions summarized in this paper are solely those of the authors and do not reflect the official opinion of any affiliated organization.

(C) 2000 by Andrew Haughwout and Robert P. Inman. All rights reserved. Short sections of text, not to exceed two paragraphs, may be quoted without explicit permission provided that full credit, including (C) notice, is given to the source. 
Fiscal Policies in Open Cities with Firms and Households

Andrew Haughwout and Robert P. Inman

NBER Working Paper No. 7823

August 2000

JEL No. H3, H7, R5

\section{$\underline{\text { ABSTRACT }}$}

With the renewed interest in cities as economic centers comes a need to understand how local public services and local taxes are likely to affect city economic performance. This paper provides an equilibrium model of an open city economy with mobile firms and resident workers. Given household preferences and firm technologies and an exogenous configuration of city tax rates and national grants and fiscal mandates, the model calculates equilibrium values for firm production and input use, household consumption and housing choices, city wages, rents, and population, and finally, local tax bases, revenues, and public goods provision. The model is calibrated to the Philadelphia economy for FY 1998; model predictions are compared to recent econometric estimates of the effects of city fiscal policy on the Philadelphia private economy. We then explore two important questions for the city's fiscal future: What are the economic and fiscal consequences of raising city tax rates? Can the city shoulder a rising burden of local welfare payments and remain a viable economic center in the long-run? We find the city to be near the top of its total revenue hill and incapable of bearing significant increases in local responsibility for welfare transfers.

Andrew Haughwout

Domestic Research Department Federal Reserve Bank, New York 33 Liberty Street New York, NY 10045-001 andrew.haughwout@ny.frb.org
Robert P. Inman

Department of Finance

Wharton School

University of Pennsylvania

Philadelphia, PA 19104

and NBER

inman@wharton.upenn.edu 
Fiscal Policy in Open Cities with Firms and Households

by

Andrew Haughwout and Robert Inman

\section{Introduction}

With the renewed societal interest in cities as centers of business activity and residential life has come a renewed academic interest in how cities function as economic locations (Glaeser, 2000). Understanding why firms and households choose to locate within one city or another, or perhaps in no city at all, becomes essential information for those wishing to design an economic geography which promotes efficiency and long-run economic growth (Ciccone and Hall, 1996). Local public services and local taxes are sure to play an essential role in shaping this geography. This paper develops a general equilibrium model of an open city economy with fully mobile firms and households to examine the consequences of alternative city and national fiscal policies on the equilibrium economic prospects of the city. City firms must earn the competitive after-tax rate of return on capital, city workers must earn their competitive after-tax wage, and city residents living and working within the city must receive an overall level of utility comparable to what they might obtain residing outside the city.

Our city is not a Tiebout "bedroom" city; it contains firms as well as households. Firms within the city hire workers, invest in capital, and buy land. Residents living within the city consume, work, and buy housing and land. City taxes include taxes on resident and firm land, on housing and firm capital, on resident and commuter wages, and on resident consumption and firm production. City tax revenues, joined with exogenous grants-in-aid, are used to purchase 
a single pure public good ("infrastructure") which benefits households and firms within the city. The city contains unemployed poor and retired elderly households who receive a nationally funded income or social security grant from which they purchase consumption, housing, and land services within the city. The poor and the elderly pay taxes and consume public goods; they do not move from our city.

Our analysis extends the earlier work of Polinsky and Rubinfeld (1978) and Sullivan (1985) who also use an open city model to study the equilibrium effects of property taxation on firms and households. ${ }^{1}$ Like Polinsky-Rubinfeld we include public goods in our analysis; like Sullivan our property tax can tax land and structures at differential rates. We extend these two papers by including, in addition to property taxation, taxation of resident and non-resident labor income, resident consumption, and firm sales. The specification of the private economy follows that in Rosen (1979) and Roback (1982). As in their model we assume an exogenous city geography; resident wages and city land rents are endogenous. We solve the model numerically, calibrating household preferences and firm technologies to match best current evidence for household demands and for firm input choices in a spatial economy with public goods. The

1 The literature on local government fiscal policy uses three alternative settings for analysis. The first is the usual Tiebout framework with small open communities with mobile households but without firms; see Wildasin (1986) for a review. These communities are best thought of as bedroom suburbs. A second specification studies local fiscal policies with mobile households but now with mobile firms as well. This is our framework and seems a reasonable approach for studying fiscal policies of a single, large city with fixed land areas. In addition to Polinsky and Rubinfeld (1978) and Sullivan (1985), other important early contributions using this approach include Wilson (1986) and Zodrow and Mieszkowski (1986); again see Wildasin (1986) or now Wilson (1999) for reviews. The third approach specifies city economies with firms, but the city economies are closed in that households cannot exit, but land area of the "city" is allowed to vary; see, for example, Arnott and MacKinnon (1977) or more recently Pasha and Ghaus (1995). This third approach seems best suited for studying fiscal policies in a single metropolitan region. 
exogenous demographic (poverty and elderly populations), spatial (land area) and policy (grantsin-aid; inherited infrastructure) parameters of our model are chosen to match the demographic, spatial, and policy environment of Philadelphia, PA for the fiscal year (FY) 1998. Calibrating our model to the Philadelphia city economy has the advantage of allowing us to validate the model's performance, first with respect to its predictions for Philadelphia's private and public economies, and second, with respect to how the Philadelphia economy might react to exogenous changes in city tax rates. The calibrated model's predictions are qualitatively similar to, and with one important exception (property taxation) also quantitatively close to, the actual econometrically estimated effects of city tax policy on the Philadelphia private economy.

Section II describes the model. Section III calibrates the model to the city of Philadelphia for FY 1998 and compares the model's predicted equilibrium outcomes and market responses to tax policy changes to the actual performance of the Philadelphia economy in FY 1998. Using the calibrated model we then explore two important questions for the city's fiscal future: What are the economic and fiscal consequences of raising city tax rates, and, Can the city shoulder a rising burden of local welfare payments and remain a viable economic center in the long-run? Section IV summarizes our analysis and suggests directions for further research.

\section{Fiscal Policy in a Large Open City}

In today's increasingly open economies, individual large cities offer only one of many competitive locations for residents and firms. Capital, labor, and households are mobile, both across locations in a given economic region and between regions. Capital located in a city must earn the competitive rate of return, goods produced within the city must sell at competitive 
world prices, labor working in the city but living in the suburbs must earn their competitive after-tax wage, and residents living and working within the city must receive an overall level of utility comparable to that available outside the city. Our analysis extends the original general equilibrium model of Rosen (1979) and Roback (1982) for large open cities with fixed land areas to include the effects of fiscal policy on the private economy. Firms, resident city workers, and commuter managers are the active players in the local economy in that they can move into, or out of, the city. Our model also introduces into the city a resident dependent population of poor and elderly households who do not work. The dependent population is exogenous; these residents do not move from our city. They receive an income grant, perhaps funded in part by the working residents and firms within the city, from which they consume goods and services and buy city land and housing. A local public sector completes the model. The budget of the local government is required to be balanced. For each exogenously chosen combination of local tax rates, the model computes equilibrium local tax revenues. Local tax revenues together with exogenous, centrally-funded grants-in-aid less exogenous transfers to poor/elderly households are used to finance a single pure public good, which we think of as local public infrastructure. ${ }^{2}$

2 There is much discussion in the local public finance literature as to the correct specification for the degree of congestion in local public services; see Inman (1979). For services such as education, trash pick-up, and police and fire protection the best available evidence suggests these goods are fully congestible once community population exceeds 20,000 residents. Assuming significant externalities from these congestible services would allow us to still treat them, on the margin at least, as pure public goods. Matters are less controversial for those public services with large infrastructure needs such as roadways, ports, public transit, and water treatment; these services are well described by a noncongestible, pure public goods technology; see Haughwout (2000). 


\section{A. Firms, Working Residents, and Commuters}

Firms within the city buy capital $(K)$, land $\left(L_{f}\right)$, resident worker $(N)$, and non-resident commuter managers $(M)$ to produce a common consumption good $(X)$ to be sold at constant world price $\mathrm{P}_{\mathrm{X}}$, normalized to $1 ; X$ may be consumed within the city by city residents or exported. All endogenous variables of the model are denoted in italics. The production technology for city firms is assumed to be constant returns to scale (linear homogeneous) over these four private market inputs. Firms also use the endogenously provided all-purpose public good $(G)$ as a production input; $G$ is assumed to influence firm production as a beneficial Hicksneutral shift in the marginal productivities of the private inputs. Firms buy capital at its exogenous market price ( $=1$ ) and pay an annual cost of capital equal to the competitive rate of return (r) plus any local property tax $\left(\tau_{\mathrm{p}}\right)$ levied on the value of that capital stock $(=1 \cdot K)$. Firms use land within the city and pay the annual rental rate $(R)$ plus the property tax $\left(\tau_{\mathrm{p}}\right)$ on the value of that land $\left(=(R / \mathrm{r}) \cdot L_{f}\right)$. The model includes two kinds of labor: resident workers and commuter managers. While this specification conveniently describes labor's location in the United States, the model itself is sufficiently general to allow managers to live within the city and workers to be commuters, perhaps a more appropriate specification for European and South American cities. Firms hire resident labor $(N)$ at the endogenously determined resident wage (W). Finally, firms hire non-resident managers $(M)$ and pay these managers their competitive (exogenous) non-resident wage (S) inclusive of any compensation for city disamenities plus a compensating differential for commuter labor taxes imposed by the city at the rate $\tau_{\mathrm{m}}$. The gross-of-tax wage paid by city firms to commuter managers equals $\left(1+\tau_{\mathrm{m}}\right) \cdot \mathrm{S}$.

For production efficiency, firms within the city maximize output defined by their 
common constant returns production technology needed to produce one unit of $X$, given $\mathrm{G}-1$ $=\mathrm{X}\left(k, n, m, \ell_{f} ; \mathrm{G}\right)$, where $k=K / X, n=N / X, m=M / X, \ell_{f}=L_{f} / X$-- subject to an exogenous vector of local tax rates $\left(\tau_{\mathrm{f}}=\left\{\tau_{\mathrm{p}}, \tau_{\mathrm{m}}\right\}\right)$, the resulting level of the pure public good $(G)$, and a constant average cost constraint inclusive of local tax payments: $\mathrm{c}=\left[\mathrm{r}+\tau_{\mathrm{p}}\right] \cdot k+W \cdot n+$ $\left[1+\tau_{\mathrm{m}}\right] \cdot S \cdot m+\left[\mathrm{r}+\tau_{\mathrm{p}}\right] \cdot(R / \mathrm{r}) \cdot \ell_{f}$. The resulting firm demands for factor inputs, specified here as demand per unit output, are:

$$
\begin{gathered}
k=\mathrm{k}\left(R, W ; \tau_{\mathrm{f}}, G ; \mathrm{r}, \mathrm{S}\right) ; \\
n=\mathrm{n}\left(R, W ; \tau_{\mathrm{f}}, G ; \mathrm{r}, \mathrm{S}\right) ; \\
m=\mathrm{m}\left(R, W ; \tau_{\mathrm{f}}, G ; \mathrm{r}, S\right) ; \text { and } \\
\ell_{f}=\ell_{\mathrm{f}}\left(R, W ; \tau_{\mathrm{f}}, G ; \mathrm{r}, \mathrm{S}\right) .
\end{gathered}
$$

The long-run equilibrium does not allow city firms to make excess profits or losses solely because of city location. City firms' long-run average costs must therefore equal the competitive price of the produced good ( $\equiv 1$ 1) less any city taxes imposed on the value of the firms' gross output $\left(\tau_{x}\right)$. Based upon the factor demand curves above, the firms' zero excess profit constraint will be defined as average revenue $(\$ 1)$ minus per unit taxes $\left(\tau_{\mathrm{x}}\right)$ minus average cost: ${ }^{3}$

$$
1-\tau_{\mathrm{X}}-\mathrm{c}\left(R, W ; \tau_{\mathrm{f}}, G ; \mathrm{r}, \mathrm{S}\right)=\Pi_{0}\left(R, W ; \tau_{\mathrm{X}}, \tau_{\mathrm{f}}, G ; \mathrm{r}, \mathrm{S}, 1\right)=0
$$

${ }^{3}$ Implicit in this specification of the firm's after-tax profits are four assumptions which define the initial incidence of local taxation on firms. First, the supply of capital equipment is perfectly elastic; firms therefore bear the initial burden of the portion of the local property tax which falls on firm capital. Second, there is a perfectly elastic supply of suburban workers to city firms; firms therefore bear the initial burden of a non-resident wage tax. Third, all firms own land in the city; firms therefore bear the burden of the portion of the local property tax which falls on firm owned land. Fourth, there is an elastic demand for city firm output in the world market; city firms therefore bear the initial burden of any tax imposed by the city on firm output. Given the assumptions of our model, the final burden of these local taxes will be shifted back onto land values. 
Working residents living in the city consume three private goods -- an all-purpose consumption good $\left(x_{r}\right)$, housing structures $\left(h_{r}\right)$, and residential land $\left(\ell_{r}\right)-$ and the all-purpose pure public good $(G)$. Work effort by working residents is exogenous; there is no labor-leisure choice in our model. The residents are assumed to purchase the three private goods $\left(x_{r}, h_{r}, \ell_{r}\right)$. Consumption goods $\left(x_{r}\right)$ are purchased at an exogenous world price $(\equiv 1)$ plus any local sales tax levied on consumption $\left(\tau_{s}\right) \cdot{ }^{4}$ Housing structures are constructed at the competitive price ( $=$ 1) and paid for through an annual rental cost sufficient to return a competitive rate of return (r). Households purchase land within the city at an endogenously determined annual rental price $(R)$ and pay the local property tax $\left(\tau_{\mathrm{p}}\right)$ levied on the value of land $\left(=(R / \mathrm{r}) \cdot \ell_{\mathrm{r}}\right)$ and structures $(=$ $\left.1 \cdot h_{r}\right)$. Total household expenditures on goods, housing, and land inclusive of tax payments may not exceed annual resident wage $(W)$ earned by working at city jobs, net of city wage taxes paid at rate $\tau_{\mathrm{W}}:\left[1+\tau_{\mathrm{s}}\right] \cdot x_{\mathrm{r}}+\left[\mathrm{r}+\tau_{\mathrm{p}}\right] \cdot h_{r}+\left[\mathrm{r}+\tau_{\mathrm{p}}\right] \cdot(R / \mathrm{r}) \cdot \ell_{\mathrm{r}}=\left[1-\tau_{\mathrm{w}}\right] \cdot W^{5}$ Residents maximize a common, well-behaved utility function $\mathrm{U}\left(x_{r}, h_{r}, \ell_{r} ; \mathrm{G}\right)$ subject to this budget constraint, a vector

${ }^{4}$ Requiring residents to consume $x$ within the city removes the effect of local sales taxes on cross-border shopping; see, for example, Walsh and Jones (1988) and most recently Goolsbee (1999) for evidence. Alternatively, in our model residents are free to (costlessly) leave the city when the sales tax is increased.

5 Implicit in this specification of the household budget constraint are four assumptions which define the initial incidence of local taxation. First, the supply of consumption goods $(x)$ is perfectly elastic to city residents; residents therefore bear the initial burden of the local sales tax. Second, there is a perfectly elastic supply of housing structures to city residents; residents therefore bear the initial burden of the portion of the property tax which falls on structures. Third, all residents own land in the city; residents therefore bear the burden of the portion of the local property tax which falls on resident owned land. Fourth, given the full mobility of both firms and workers, worker supply and demand are elastic; we assume that residents therefore bear the initial burden of the resident wage tax. These initial incidence assumptions do not affect the equilibrium incidence of local taxation, which is the focus of our analysis. 
of exogenous local resident tax rates $\left(\tau_{\mathrm{r}}=\left\{\tau_{\mathrm{s}}, \tau_{\mathrm{p}}, \tau_{\mathrm{w}}\right\}\right)$, and the exogenous level of the local public good (G). Resulting resident demand curves for $x_{r}, h_{r}$, and $\ell_{r}$ are specified as:

$$
\begin{gathered}
x_{r}=\mathrm{x}_{\mathrm{T}}\left(R, W ; \tau_{\mathrm{r}}, G ; \mathrm{r}, 1\right) ; \\
h_{r}=\mathrm{h}_{\mathrm{r}}\left(R, W ; \tau_{\mathrm{r}}, G ; \mathrm{r}, 1\right) ; \text { and }, \\
\ell_{r}=\ell_{\mathrm{r}}\left(R, W ; \tau_{\mathrm{r}}, G ; \mathrm{r}, 1\right) .
\end{gathered}
$$

The long-run equilibrium requires that residents or households planning to live within the city achieve the same level of utility as available to them outside the city. Given the household's demands for $x_{r}, h_{r}$, and $\ell_{r}$, the indirect utility function for a typical resident can be specified and set equal to the exogenous utility $\left(\mathrm{V}_{0}\right)$ available outside the city:

$$
\mathrm{V}\left(R, W ; \tau_{\mathrm{r}}, G ; \mathrm{r}, 1\right)=\mathrm{V}_{0} .
$$

Commuting managers consume private goods, housing, and land at their suburban residential location outside the city. We assume that commuters are able to buy private goods and housing at constant world prices. Commuters have the option of working at a suburban location. As noted, to attract these workers into city jobs requires city firms to pay a wage equal to the commuters' suburban wage inclusive of compensation for all (assumed exogenous) disamenities of working within the city -- e.g., the city's taxation of commuters' labor income. This compensating wage is equal to $\left(1+\tau_{\mathrm{m}}\right) \cdot \mathrm{S}$, where $\tau_{\mathrm{m}}$ is the commuter wage tax rate; $\left(1+\tau_{\mathrm{m}}\right) \cdot \mathrm{S}$ is sufficient to give suburban commuters the model's equilibrium level of residential utility, $\mathrm{V}_{0}{ }^{6}$

6 While we allow city firms to distinguish between city and suburban workers, we assume city firms cannot distinguish among suburban workers by their residential location in the suburbs. Thus a single wage will be paid to all suburban workers in our model and the suburban economy can then be specified as a standard "bid-rent" economy. Suburban land values will then reflect the differential costs of commuting into the central city. City 


\section{B. Dependent Households}

The city is assumed to contain a fixed, immobile population of (D) dependent poor and elderly households who each receive an exogenous income transfer of $\mathrm{Y}$ dollars paid for by the central government and perhaps in part, through local taxation, by the city government as well. Dependent households consume the composite private good $\left(x_{d}\right)$, housing $\left(h_{d}\right)$, and land $\left(\ell_{d}\right)$ and pay taxes on their consumption. They do not pay taxes on their exogenous income transfer (Y). Dependent households also consume the pure public good $(G)$ provided by the city government. We assume dependent households do not move from the city. ${ }^{7}$ Dependent households maximize their household utility function, $\mathrm{U}\left(x_{d}, h_{d}, \ell_{r} ; \mathrm{G}\right)$ subject to the vector of exogenous local resident tax rates $\left(\tau_{d}=\left\{\tau_{s}, \tau_{p}\right\}\right)$, the exogenous level of the local public good (G), and a dependent household budget constraint: $\left[1+\tau_{\mathrm{s}}\right] \cdot x_{d}+\left[\mathrm{r}+\tau_{\mathrm{p}}\right] \cdot h_{d}+\left[\mathrm{r}+\tau_{\mathrm{p}}\right] \cdot(R / \mathrm{r}) \cdot \ell_{d}=\mathrm{Y}$. The resulting dependent resident demand curves for $x_{d}, h_{d}$, and $\ell_{d}$ are specified as:

$$
\begin{gathered}
x_{d}=\mathrm{x}_{\mathrm{d}}\left(R ; \mathrm{Y}, \tau_{\mathrm{d}}, G ; \mathrm{r}, 1\right) ; \\
h_{d}=\mathrm{h}_{\mathrm{d}}\left(R ; \mathrm{Y}, \tau_{\mathrm{d}}, G ; \mathrm{r}, 1\right) ; \text { and, } \\
\ell_{d}=\ell_{\mathrm{d}}\left(R ; \mathrm{Y}, \tau_{\mathrm{d}}, G ; \mathrm{r}, 1\right) .
\end{gathered}
$$

Given their demands for $x_{d}, h_{d}$, and $\ell_{d}$, the indirect utility function for a typical dependent household can be specified as:

$$
\mathrm{V}\left(R ; \mathrm{Y}, \tau_{\mathrm{d}}, G ; \mathrm{r}, 1\right)=V_{d} .
$$

commuters will outbid suburban workers for land closer to the central city.

7 For evidence that the average welfare household is not very sensitive to fiscal incentives in its location decisions, see Meyer (1999). Epple and Romer (1991) allow for mobile rich and poor households in their model of an open city in a metropolitan economy, but in their model all household incomes are exogenous. 
Since dependent households cannot escape the city, their equilibrium level of utility $\left(V_{d}\right)$ is endogenous.

\section{City Government}

In each fiscal year the city government uses its flow of city net revenues to purchase access to a new stock of public infrastructure $(\Delta G)$. The city's net revenues per capita are defined as the sum of the endogenous annual flow of local tax revenues per resident $(\Re)$ plus additional city resources obtained from an exogenous level of intergovernmental grants per resident $(Z)$ plus income earned from the exogenous "inherited" net financial wealth per resident (A) less required city spending per resident to support the city's dependent population (= $\psi \cdot \mathrm{Y} \cdot \delta$, where $\psi$ is the required rate of city support and $\delta=\mathrm{D} /(N+\mathrm{D})$ is the share of total city population who are dependent). Income earned from the net financial wealth of the city (A) equals interest, dividends, and capital appreciation on city financial assets less interest paid on city financial liabilities. In the United States, the most important financial liability of cities are their unfunded public employee pensions; interest costs associated with public infrastructure are treated separately below. Given net revenues, the city can purchase and maintain new infrastructure at an annual cost of $(r+\sigma) \cdot \Delta G$, where $r$ is the annual cost to the city of borrowed funds to purchase $\Delta \mathrm{G}$ and $\sigma$ is the depreciation rate for the new stock of public capital just purchased. ${ }^{8}$ The stock of new infrastructure which can be supported by the equilibrium annual flow of net city revenues per capita is therefore: $\Delta G=\{\Re+\mathrm{Z}+\mathrm{A}-\psi \cdot \mathrm{Y} \cdot \delta\} \cdot[N+$

8 The annual interest rate paid by the city is set here at the private rate of $r$. In the United States, tax-exempt status for state and local government debt creates a subsidy for individual city borrowing such that the U.S. city borrowing rate is $r_{m}=(1-t) \cdot r$, where $t$ is the federal income tax rate of the marginal investor in city debt; see Poterba (1989). Our simulation analysis for Philadelphia will allow for this extension. See Section III.A below. 
$\mathrm{D}] /(\mathrm{r}+\sigma)$, where $[N+\mathrm{D}]$ is total city population. Since public infrastructure is a pure public good, the equilibrium level of per capita net city revenues must be multiplied by the equilibrium population, and then divided by $(r+\sigma)$ to define the aggregate stock of new infrastructure $(\Delta G)$ available to residents and firms.

In addition to the purchase of new infrastructure, cities may "inherit" an aggregate stock of public infrastructure $\left(\mathrm{G}_{0}\right)$ accumulated in prior years but which still provides benefits to current residents. This inherited stock is not totally free, however. There may be annual interest costs still due on the inherited stock $\left(=r^{\circ} \cdot G_{0}\right)$ and there will be an annual replacement costs of $\sigma \cdot \mathrm{G}_{0}$ for that portion of $\mathrm{G}_{0}$ which depreciates each year. These expenses cost the city $\left(r^{\circ}+\sigma\right) \cdot \mathrm{G}_{0}$ annually to maintain the inherited stock $\mathrm{G}_{0}$. Paying $\left(\mathrm{r}^{\circ}+\sigma\right) \cdot \mathrm{G}_{0}$ each year will reduce city residents' access to new infrastructure by $\left(\mathrm{r}^{\circ}+\sigma\right) \cdot \mathrm{G}_{0} /(\mathrm{r}+\sigma)$. The net gain from inherited infrastructure will be: $\mathrm{G}_{0}-\left(\mathrm{r}^{\circ}+\sigma\right) \cdot \mathrm{G}_{0} /(\mathrm{r}+\sigma)=\left[\left(\mathrm{r}-\mathrm{r}^{\circ}\right) /(\mathrm{r}+\sigma)\right] \cdot \mathrm{G}_{0}$. The only portion of inherited city infrastructure that will be valuable to city residents, and thus affect the current city equilibrium, will be that portion which has been fully purchased by prior residents. This portion equals $\left[\left(r-r^{\circ}\right) /(r+\sigma)\right] \cdot G_{0}$.

Infrastructure purchased from the equilibrium flow of net city revenues together with the unencumbered portion of the inherited infrastructure define the equilibrium level of the city's public infrastructure available for household and firm consumption in equilibrium. The equilibrium level of $\mathrm{G}$ is therefore:

$$
G=\Delta G+\left[\left(\mathrm{r}-\mathrm{r}^{\circ}\right) /(\mathrm{r}+\sigma)\right] \cdot \mathrm{G}_{0}
$$

or, alternatively:

$$
G=\{\Re+\mathrm{Z}+\mathrm{A}-\psi \cdot \mathrm{Y} \cdot \delta\} \cdot[N+\mathrm{D}] /(\mathrm{r}+\sigma)+\left[\left(\mathrm{r}-\mathrm{r}^{\circ}\right) /(\mathrm{r}+\sigma)\right] \cdot \mathrm{G}_{0} .
$$


Equation (14) is an implicit function of $G$ since equilibrium values of $\Re, N$, and $\delta$ each depend on $G$.

City tax revenues per capita are determined as the product of an exogenously chosen city tax rates $\left(\tau_{\mathrm{i}}, \mathrm{i}=\mathrm{p}, \mathrm{s}, \mathrm{w}, \mathrm{m}\right.$, and $\left.\mathrm{X}\right)$ multiplied by the corresponding endogenously specified equilibrium tax base per capita $\left(B_{i}, \mathrm{I}=\mathrm{p}, \mathrm{s}, \mathrm{w}, \mathrm{m}\right.$, and $\left.\mathrm{X}\right)$, then summed over all taxes:

$$
\Re=\Sigma_{\mathrm{i}} \tau_{\mathrm{i}} \cdot B_{i} .
$$

Noting that $\delta(=\mathrm{D} /(N+\mathrm{D}))$ is the equilibrium share of city population who are dependent and $(1-\delta)(=N /(N+\mathrm{D}))$ is the equilibrium share of the city population who work, we can define each equilibrium tax base per capita as:

(15a) $B_{p}=(1-\delta) \cdot\left[k / n+(R / r)\left\{\ell_{r}+\left(\ell_{f} / n\right)\right\}+h_{r}\right]+\delta \cdot\left[(R / r) \ell_{d}+h_{d}\right]$, for city property taxation;

$$
B_{s}=(1-\delta) \cdot x_{r}+\delta \cdot x_{d} \text {, }
$$

for city sales taxation;

$$
B_{w}=(1-\delta) \cdot W,
$$

for resident wage taxation;

$$
B_{m}=(1-\delta) \cdot S \cdot m / n,
$$

for non-resident commuter taxation; and

$$
B_{X}=(1-\delta) / n,
$$

and for gross receipts taxation (remembering that $n$ is resident-worker per unit of local output).

\section{Aggregate Economic Output and City Demographics}

Aggregate output produced within the city $(X)$ is determined by equating the aggregate land requirements of city firms to the exogenous aggregate supply of land within the city 
available for production. The aggregate land requirements needed by city firms to produce aggregate output $X$ equals the sum of firm land needed directly in production $\left(\ell_{f} \cdot X\right)$ plus all the land needed to house the firms' resident workers $\left(\ell_{r} \cdot n \cdot X\right)$; that is, $\mathscr{L}_{d}=\ell_{f} \cdot X+\ell_{r} \cdot n \cdot X$. The aggregate supply of land available to accommodate firms and resident workers -- and thus permit the production of aggregate output $X$-- will equal the exogenous supply of land in the city $\left(\mathscr{L}_{\mathrm{s}}\right)$ less the amount of land consumed by dependent residents $\left(\ell_{d} \cdot \mathrm{D}\right)$. Setting the supply of available land equal to the amount of land required for the production of $X$ specifies aggregate city output as:

$$
X=\left[\mathscr{L}_{s}-\ell_{d} \cdot \mathrm{D}\right] /\left[\ell_{f}+\ell_{r} \cdot n\right]
$$

In equilibrium, our city may be either an export or an import city of the consumption good. When aggregate output exceeds (is less than) aggregate residential consumption $\left(X>(<) x_{r} \cdot N\right.$ $\left.+x_{d} \cdot \mathrm{D}\right)$ the city is a net exporter (importer) of the consumption good.

City demographics follow city economics. Knowing the level of aggregate city output $(X)$, the total population of resident workers must be:

$$
N=n \cdot X
$$

With population of city resident workers now specified, total city population is $N+\mathrm{D}$, where $\mathrm{D}$ is the exogenously specified dependent population. The dependent population's share of total city population is specified as:

$$
\delta=\mathrm{D} /[N+\mathrm{D}]
$$

\section{E. Specifying the Open City Equilibrium}

An open city equilibrium exists within our model when no mobile firm, resident household, or commuter has an incentive to change their location, residence, or job. This means 
satisfying eqs. (5) and (9) and ensuring commuters get their after-tax wage of $S$. An equilibrium specifies the model's 18 endogenous variables: the two local market prices $(R, W)$; firm input purchases per unit output $\left(k, n, m, \ell_{f}\right)$; working residents' consumption $\left(x_{r}, h_{r}, \ell_{r}\right)$; dependent residents' consumption $\left(x_{d}, h_{d}, \ell_{d}\right)$ and utility $\left(V_{d}\right)$; city government revenues $(\Re)$ and public goods $(G)$; the economic $(X)$ and demographic $(N)$ size of the city, and, finally, the demographic composition of the city $(\delta)$. The 18 equations of the model specified above are sufficient to solve for each of the 18 endogenous variables, conditional on values for each of the model's exogenous parameters: city tax rates $\left(\tau_{\mathrm{p}}, \tau_{\mathrm{s}}, \tau_{\mathrm{w}}, \tau_{\mathrm{m}}, \tau_{\mathrm{x}}\right)$, the world interest rate $(\mathrm{r})$, the world price of the locally produced and consumed consumption good (1), a commuter's compensating wage (S), a dependent resident's annual transfer income $(Y)$, the share of dependent's transfer income supported by local taxes $(\psi)$, the city's intergovernmental aid (Z), the city's income from inherited financial assets (A), the rate of depreciation of public infrastructure $(\sigma)$, the city's inherited stock of public infrastructure $\left(\mathrm{G}_{0}\right)$, and the rate of interest payments still due on that inherited stock $\left(\mathrm{r}^{\circ}\right)$.

The model is solved iteratively. First, given preferences and technologies, world prices $(r, 1, S)$ and the firms' and resident-workers' outside options $\left(\Pi_{0}, V_{0}\right)$, local tax rates $\left(\tau_{\mathrm{p}}, \tau_{\mathrm{s}}, \tau_{\mathrm{w}}\right.$, $\left.\tau_{\mathrm{m}}, \tau_{\mathrm{x}}\right)$ and an assumed starting value for $G\left(=\mathrm{G}^{(0)}\right)$, eqs. (5) and (9) specify two equations in the two unknown endogenous city prices, $W$ and $R$; see Figure 1 . The firm profit constraint (eq. (5)) is shown as one of a family of the declining profit curves, $\Pi_{0}(\cdot)=0$, in the $\{R, W\}$ space. The household utility constraint (eq. (9)) is represented by one of a family of rising indifference curves, $\mathrm{V}(\cdot)=\mathrm{V}_{0}$, which define the (increasing) willingness of households to pay for land as the local wage increases. Citizens will be better off if they can move to an indifference curve 
below $\mathrm{V}_{0}$ (earning higher wages and/or paying lower rents) and firms will be more profitable by moving to a profit curve below $\Pi_{0}(\cdot)=0$ (paying lower wages and rents). The equilibrium wage $(W)$ and rent $(R)$ defined by the intersection of $V_{0}(\cdot)$ and $\Pi_{0}(\cdot)$ in Figure 1 are consistent with each resident receiving $\mathrm{V}_{0}$ and each city firm receiving no excess profits or losses. Initially, the equilibrium values of wages and rents will be $W=\mathrm{W}^{(0)}$ and $R=\mathrm{R}^{(0)}$, both conditional upon the assumed starting value of $G=\mathrm{G}^{(0)}$.

Given $\mathrm{W}^{(0)}$ and $\mathrm{R}^{(0)}$, eqs. (1)-(4), (6)-(8), and (10)-(12) can then be solved for firms' input demands, resident workers' demands, and dependent residents' demands, respectively, again conditional upon $G=\mathrm{G}^{(0)}$. Eq. (13) defines dependent resident's utility $\left(V_{d}^{(0)}\right)$. Firms' and residents' demands for land $\left(\ell_{f}^{(0)}, \ell_{d}^{(0)}, \ell_{r}^{(0)}\right)$ and firms' demand for workers $\left(n^{(0)}\right)$ allow us to compute aggregate city output $\left(X^{(0)}\right)$ from eq. (16), aggregate resident employment $\left(N^{(0)}\right)$ from eq. (17), and the dependent population's share of total city population $\left(\delta^{(0)}\right)$ from eq. (18). Given conditional firms' and residents' demands, rents and wages, and now the dependent residents' share of city population, city own tax revenues $\left(\Re^{(0)}\right)$ can be calculated from eq. (15), using eqs. (15a)-(15e). Finally, having specified $\Re^{(0)}, N^{(0)}$, and $\delta^{(0)}$, eq. (14) can be now solved for a new starting value of $G=\mathrm{G}^{(1)}$, and the solution process repeated.

An equilibrium is obtained when $\mathrm{G}^{(-1-1)}=\mathrm{G}^{(t)}=G$; that is, when a starting value of $\mathrm{G}$ creates a private economy and subsequent public goods resources as specified by eq. (14) just sufficient to pay for the original starting level of G. Sufficient for an equilibrium level of G to be a locally stable equilibrium is for a small increase (decrease) in $\mathrm{G}$ from equilibrium to cost (save) more than any endogenous public goods resources generated (lost), at given tax rates, after the private economy's adjustments to that change in G. Simply put, for given tax rates 
Figure 1

\section{Rent-Wage Equilibrium in an Open City Philadelphia, 1998}

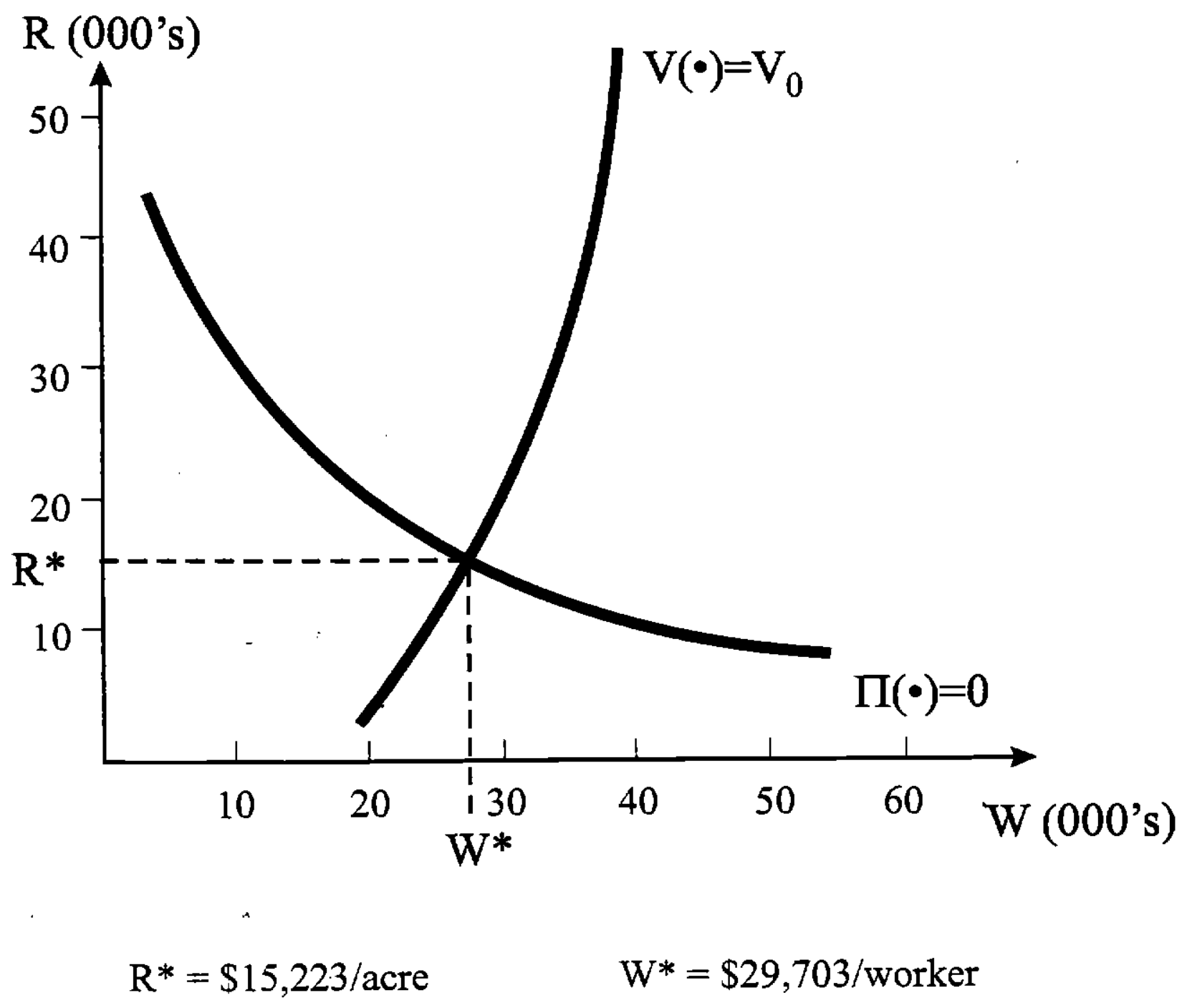


increasing $\mathrm{G}$ cannot, in equilibrium, be a source of new wealth (i.e., a "money machine") for the city's current residents. ${ }^{9}$ All simulations reported in Sections III and IV for one plausible city economy (Philadelphia) produced stable and unique equilibria.

\section{Fiscal Policy in One Open City: Philadelphia, FY 1998}

\section{A. Model Calibration: Philadelphia, FY 1998}

Solution of our open city fiscal model requires specifications for household preferences and the firm production technology and then selection of each of the model's exogenous parameters. Table 1 summarizes the model's specification for the city of Philadelphia, PA for the Fiscal Year (FY), 1998.

The city's firms' technology is represented by a Cobb-Douglas specification between land $(L)$ and a composite joint labor-capital input produced by a CES combination of resident workers $(N)$, commuter managers $(M)$, and firm capital $(K)$. Managers and laborers may be either substitutes or complements. Our parameter specification for the degree of complementarity between $M$ and $K$ and substitutability between $N$ and the $M-K$ composite are from Krusell, Ohanian, Rios-Rull, and Violante (1998). ${ }^{10}$ Consistent with their evidence, firm capital $(K)$ is

9 Specifying eq. (14) generally as the implicit function $G=g(G ;[\cdot])$, where $[\cdot]$ is a vector of all exogenous variables of the model including city tax rates, then at any stable equilibrium must meet two conditions: 1) $G=\mathrm{g}(G ;[\cdot])$ and 2$) \mathrm{dg} / \mathrm{d} G<1$. This stability condition is likely to be violated only when small increases in public goods lead to large upward shifts in the $V_{0}$ and $\Pi_{0}$ curves in Figure 1 , thereby generating very large increases in city rents and/or city wages. This can occur only when $\mathrm{G}$ has a large marginal product in firm production and/or a large marginal benefit $(=-(\partial U / \partial G) / \partial U / \partial x))$ in household preferences.

10 The general specification for the production technology is: 
Table 1: Model Calibration for Philadelphia, FY 1998

\section{Firm Production}

$$
X=L_{f}^{.05}\left[.5 N^{.40}+.5\left[.5 K^{-.50}+.5 M^{-.50}\right]^{.40 /(-.50)}\right]^{.95 / .40} G^{.04}
$$

\section{Household Utility}

$$
U_{r, d}=x_{r, d}^{.75} h_{r, d}^{.20} \ell_{r, d}^{.05} G^{.05}
$$

Fiscal Policy, Philadelphia, FY 1998

$$
\begin{aligned}
& \tau_{p}=.0249 \\
& Z=\$ 3,753 / \text { household } \\
& G_{0}=\$ 16.92 \text { billion } \\
& \tau_{s}=.007 \\
& A=-\$ 232 / \text { household } \\
& r^{0}=.0052 \\
& \tau_{w}=.0479 \\
& Y=\$ 13,500 / \text { dependent household } \\
& \sigma=.03 \\
& \tau_{m}=.04165 \\
& \psi=.095 \\
& r_{m}=.04 \\
& \tau_{X}=.002875
\end{aligned}
$$

\section{City Geography and Demographics}

$$
\mathcal{L}_{s}=86,400 \text { acres } \quad D=176,739 \text { households }
$$

\section{World Economy}

$$
\begin{array}{lrl}
p & =\$ 1.00 & V_{0} \equiv 1.00 \\
r & =.05 & \Pi_{0} \equiv 0.0 \\
S=\$ 45.000 &
\end{array}
$$


specified as a complement to managerial labor $(M)$, while city labor $(N)$ and the composite input of capital and managers are specified as substitutes. The relative weights on $\mathrm{K}$ and $\mathrm{M}$ within the capital/manager composite input and then the relative weight between $\mathrm{N}$ and the capital/manager composite are selected to approximate national income shares among these three inputs; see Table 2 below. The Cobb-Douglas exponent on land is set equal to .05 , following Mieszkowski (1972), Arnott and MacKinnon (1977), and Sullivan (1985). In their work estimating the production relationship used here from U.S. time series data, Krusell, et. al. (1998) use an inclusive input composed of land and structures in place of land alone and estimate the corresponding output elasticity as .11. Our choice of .05 for the land input alone seems reasonable. To ensure our technology is linear homogenous in the four market inputs, the exponent on the overall labor-capital composite is then set equal to .95 . The final elasticity measuring the marginal contribution of public infrastructure $(G)$ to firm output is set equal to .04 using estimates from Haughwout (2000) for a sample of 33 U.S. cities, including Philadelphia. Since $G$ is a pure public good funded in part through taxes on firm inputs, adding productive inputs lowers the tax cost per input of paying for $G$ without reducing the production benefits that $G$ provides; the effect on city attractiveness to firms is similar to that of introducing

$$
\mathrm{X}=\mathrm{L}_{\mathrm{f}}^{\alpha}\left[\mu \mathrm{N}^{\varepsilon}+(1-\mu)\left(\lambda \mathrm{K}^{\rho}+(1-\lambda) \mathrm{M}^{\rho}\right)^{\varepsilon / \rho}\right]^{(1-\alpha) / \varepsilon} \mathrm{G}^{\theta},
$$

where $\mu$ and $\lambda$ are the parameters which determine factor income shares, $\varepsilon$ and $\rho$ determine the elasticity of substitution between $\mathrm{N}, \mathrm{K}$, and $\mathrm{M}$, and $\alpha$ and $\theta$ determine the marginal productivities of land, the labor-capital composite input, and public infrastructure. Within the labor-capital composite input, the elasticity of substitution between capital (K) or managers $(\mathrm{M})$ and labor $(\mathrm{N})$ is $1 /(1-\varepsilon)$, while the elasticity of substitution between capital and managers is specified by $1 /(1-\rho)$. Complementarity between capital and managers requires that $\varepsilon>\rho$; see Fallon and Layard (1975). The specification in Table 1 meets this requirement as $\varepsilon=.40>-.50=\rho$. 
agglomeration economies directly into the firm technology.

Households' preferences are represented by a Cobb-Douglas utility function, implying unitary price and income elasticities of demand for the all-purpose consumption good $\left(x_{r, d}\right)$, for housing structures $\left(h_{r, d}\right)$, and for residential land $\left(\ell_{r, d}\right)$; see Rosen (1979) and more recently Gyourko and Voith (2000) for evidence consistent with unitary price and income elasticities of demand for residential housing and land. Work effort by resident workers is exogenous and suppressed in the specification of $U(\cdot)$; dependent residents do not work. Resident workers and dependent residents are assumed to have the identical preferences for $G, x, h$, and $\ell$ but, of course, not identical utilities in equilibrium. ${ }^{11} \quad$ Preferences are specified so that households allocate .75 of their annual after-wage-tax income to the all-purpose consumption good $\left(x_{r, d}\right), .20$ to housing structures $\left(h_{r, d}\right)$, and .05 to land $\left(\ell_{r, d}\right)$. These after-tax budget shares are chosen to approximate actual share allocations for typical U.S. homeowners. Local public goods $(G)$ are also included in resident-worker and dependent-resident utility, with the budget share set equal to .05 , again based upon the recent empirical work in Haughwout (2000). ${ }^{12}$ City residents in our model take city $G$ as exogenous.

To replicate the actual Philadelphia economy for FY 1998, all exogenous fiscal parameters are set equal either to Philadelphia's actual values for FY 1998 as reported in the

11 In equilibrium workers are expected to have higher incomes than dependents, and in all our simulations, they do. We cannot compare utilities of workers and dependents because we have not included leisure directly in the household utility function.

12 The budget share of .05 is also very close to the average share of income allocated to local public goods by Philadelphia suburban area households under the assumption that suburban households can choose -- ala Tiebout -- their preferred level of local public goods; see Inman and Ritter (1999). 
City of Philadelphia, Five Year Financial Plan, January 26, 1999 or to our best estimates calculated from published city fiscal data. City tax rates $\left(\tau_{\mathrm{p}}, \tau_{\mathrm{s}}, \tau_{\mathrm{w}}, \tau_{\mathrm{m}}, \tau_{\mathrm{x}}\right)$, exogenous intergovernmental grants from federal and state governments to the city and its school district exclusive of welfare assistance $(Z)$, and net income earned from the net financial wealth of the city less city contributions towards unfunded public employee pensions (A) are all reported in the city's Five Year Financial Plan, 1999. ${ }^{13}$ Transfer income of $\$ 13,500$ per dependent household (Y) reflects current average annual payments to three person households on public welfare or to two person households receiving social security. The share of transfer income paid for by city tax revenues $(\psi)$ is from Summers and Jakubowski (1997) and reflects city contributions to meet state mandates for foster care for abandoned or abused children. Inherited public infrastructure stock ( $\mathrm{G}_{0}$, billions of 1994 dollars) is estimated in Haughwout and Inman (1996, updated). The weighted average annual rate of interest still due on this inherited stock $\left(r^{\circ}\right)$ is estimated as the ratio of FY 1998 interest and principal repayments to $\mathrm{G}_{0}$ (Five Year Financial Plan, 1999, Appendix II, p. 1). The rate of depreciation of public infrastructure $(\sigma)$ is set at .03 , the same rate used for the Haughwout-Inman (1996) estimates of $\mathrm{G}_{0}$. The city's current borrowing rate $\left(r_{m}\right)$ for new infrastructure is chosen to reflect the real municipal bond interest rate for the city's FY 1998 BAA investment grade bond rating; see Economic Report of the President, 1999, Table B-73.

13 See Five Year Financial Plan, 1999 for the property tax rate on market value of property $\left(\tau_{\mathrm{p}}\right.$, adjusted for the city assessment rate) at $\mathrm{p} .9$; for the city's differential rate on local sales $\left(\tau_{s}\right.$, adjusted for the exemption of food consumption) at p. 15; for the wage tax rate on residents $\left(\tau_{\mathrm{w}}\right)$ and non-resident commuters $\left(\tau_{\mathrm{m}}\right)$ at $\mathrm{p}$. 7 ; for the gross receipts tax rate on city firm output $\left(\tau_{X}\right)$ at p. 13; for intergovernmental grants $(\mathrm{Z})$ at Appendix III, p. 1; and for interest income eamings net of contributions for pension underfunding (A) at pp. 20 and 402 , respectively. 
City land area $\left(\mathscr{L}_{s}\right)$ is measured in acres and includes all land within the city minus land used by the city's parks; see Statistical Abstract, 1994 (Table 46) adjusted by the U.S. Boundary and Annexation Survey, 1994 with park land area as reported in Five Year Financial Plan, 1999, p. 164. The city's dependent population (D) is the sum of all households with one member over the age of 65 and all households earning less than the U.S. federal poverty level. Our estimate of the number of dependent households in 1998 is computed by multiplying the share of city population 65 and older and the share of city residents living in poverty as reported in the 1990 U.S. Census of Population by the estimated 1998 city population, then dividing by the city's average household size of 2.6 residents per household. ${ }^{14}$

Finally, world prices for the all-purpose private good are normalized to $\$ 1$, world interest rates are set at $\mathbf{r}=.05$, and the Philadelphia commuter wage $(\mathrm{S})$ is set equal to the median household income of $\$ 45,000$ for a Philadelphia suburban household as estimated in the 1990 Census of Population. The level of utility available to mobile resident-workers is normalized to $V_{0} \equiv 1$ and excess profits earned by city firms at $\Pi_{0} \equiv 0$.

\section{B. Model Simulation and Validation: Philadelphia, FY 1998}

Table 2 reports the equilibrium values for all endogenous variables of the Philadelphia city economy as simulated for FY 1998. Figure 1 illustrates the equilibrium wage $\left(W^{*}\right)$ and rental price of an acre of land $\left(R^{*}\right)$; the curvatures of $\mathrm{V}_{0}$ and $\Pi_{0}$ in Figure 1 reflect the

14 Separate estimates of the average household size for elderly dependent households and for households living under poverty are not available for Philadelphia. Elderly dependent households are likely to have fewer than 2.6 members and poverty households more than 2.6 members. The overall city average of 2.6 members per household seems a reasonable approximation to the true weighted average household size for the cohort of elderly and poor dependent households. 
Table 2: Model Solution for Philadelphia, FY 1998

Prices

$W^{*}=\$ 29,703 /$ worker $\quad R^{*}=\$ 15,223 /$ acre

Firm Production

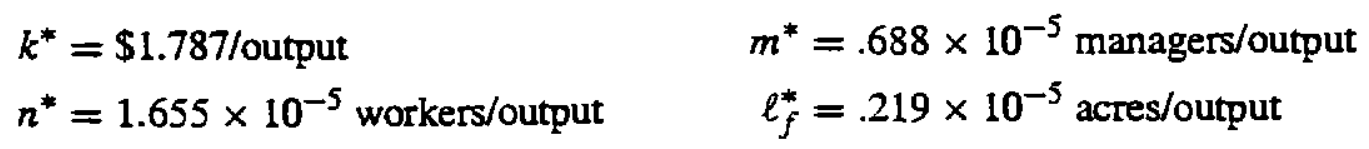

Household Consumption

$x_{r}^{*}=\$ 21,060$

$x_{d}^{*}=\$ 10,053$

$h_{r}^{*}=\$ 75,515$

$h_{d}^{*}=\$ 36,048$

$V_{d}=.477$

$\ell_{r}^{*}=.062$ acres

$\ell_{d}^{*}=.030$ acres

City Government

$\tau_{p} \cdot B_{p}^{*}=\$ 4,466 /$ household

$\tau_{s} \cdot B_{s}^{*}=\$ 125 /$ household

$\tau_{w} \cdot B_{w}^{*}=\$ 967 /$ household $^{~}$

$$
\begin{aligned}
\tau_{m} \cdot B_{m}^{*} & =\$ 529 / \text { household } \\
\tau_{X} \cdot B_{X}^{*} & =\$ 118 / \text { household } \\
\mathcal{R}^{*} & =\$ 6,205 / \text { household }
\end{aligned}
$$

$$
G^{*}=\$ 81.838 \text { billion }
$$

City Economy and Demographics

$X^{*}=\$ 22.663$ billion

$N^{*}=375.332$

$\delta^{*}=.32$ 
specifications in Table 1 for household preferences and firm technologies. ${ }^{15}$ Each unit of output ( $X^{*}$; evaluated at a price of $\$ 1$ ) produced by city firms uses $\$ 1.787$ units of firm capital $\left(k^{*}\right)$; the aggregate value of the city's firms' capital stock is therefore $\$ 40.50$ billion $\left(=X \cdot k^{*}\right)$. On average, city firms require one worker for every 60,423 units of output $\left(n^{*}\right)$, one manager for every 145,349 units of output $\left(m^{*}\right)$, and one acre of land for every 456,621 units of output $\left(\ell_{f}^{*}\right)$. Resident workers earn a $W^{*}$ of $\$ 29,703$ and city land rents equal $\$ 15,223 /$ acre. With an income of $\$ 29,703$ resident workers spend $\$ 21,060$ on the all-purpose consumption good $\left(x_{r}{ }^{*}\right)$, buy a housing stock valued at $\$ 75,515\left(h_{r}{ }^{*}\right)$, and place that stock on about $1 / 16$ th of an acre of land $\left(\ell_{r}^{*}\right) ; 1 / 16$ th of an acre is approximately the land used by a typical Philadelphia "rowhouse." The total value of a resident-worker's home $\left(=h_{r}^{*}+\left(R^{*} / \mathrm{r}\right) \cdot \ell_{r}{ }^{*}\right)$ is $\$ 94,406$; mortgage payments equal $\$ 4720$ year $(=.05 \cdot \$ 94,406)$ while local property taxes on the home are $\$ 2351 /$ year $(=.0249 \cdot \$ 94,406)$. Dependent residents receive a government transfer of $\$ 13,500$ and from their transfer income they consume $\$ 10,350\left(x_{d}^{*}\right)$, buy a housing stock worth $\$ 36,045\left(h_{d}^{*}\right)$, and place that stock on about $1 / 32$ th of an acre of land $\left(\ell_{r}^{*}\right)$, the equivalent of a city "walk-up" apartment. The total value of a dependent resident's home $\left(h_{r}^{*}+\left(R^{* / r}\right) \cdot \ell_{r}{ }^{*}\right)$

15 The underlying preference and production relationships determine the shape and slope of these curves. For Cobb-Douglas preferences, a typical indifference curve $\left(\mathrm{V}_{0}\right)$ will rise more steeply as the share of income spent on land (the exponent on $\ell_{\mathrm{r}}$ ) falls. When land is a small share of spending, an additional dollar of wage income must be offset by a large increase in land rents if utility is to remain unchanged. As wages and land costs rise, this effect is even stronger, since households are consuming smaller plots land. Thus $\mathrm{V}_{0}$ is rising at an increasing rate. A similar logic helps us to understand the shape of the firm's zero profit curve $\left(\Pi_{0}\right)$. Along $\Pi_{0}$ an additional dollar in wages must be offset by large reductions in land prices when land costs are a relatively small share of total costs (or when land's marginal productivity is low). This effect diminishes as wages rise and firms substitute land for resident labor; at high wages and low land rents firms' optimal land/labor ratio is high and smaller land price reductions are needed to offset wage increases. Thus $\Pi_{0}$ flattens as wages rise and rents decline. 
is $\$ 45,186$, and the household pays $\$ 3384 /$ year $(=(.05+.0249) \cdot \$ 45,186)$ in mortgage and property taxes. Total city taxes collected from households and firms is $\$ 6205 /$ household (= $\left.\Re^{*}\right)$, with most of the revenues coming from the property tax and the two wage taxes. The total stock of public infrastructure has a replacement cost of $\$ 81.838$ billion $\left(G^{*}\right)$. Approximately 60 percent of this infrastructure stock ( $\$ 48.9$ billion) is supported by annual tax revenues, 30 percent of the stock ( $\$ 24.5$ billion) is funded by intergovernmental grants and net interest income less local welfare contributions, and about 10 percent ( $\$ 8.4$ billion) of the stock is inherited from previous taxpayers. The equilibrium aggregate level of production in the city economy is $\$ 22.663$ billion $\left(X^{*}\right)$, while the aggregate city size is 552,071 households, composed of 375,332 resident worker households $\left(N^{*}\right)$ and 176,739 dependent resident households (D, Table 1). Aggregate consumption by city residents $\left(x_{\mathrm{r}}{ }^{*} \cdot N^{*}+x_{d}{ }^{*} \mathrm{D}\right)$ is $\$ 9.733$ billion. Philadelphia is therefore a net exporter of the locally produced consumption good; that is, $X^{*}>x_{\mathrm{r}}{ }^{*} \cdot N^{*}+$ $x_{d}{ }^{*} \mathrm{D}$.

Table 3 provides a comparison of the simulated Philadelphia economy for FY 1998 to the actual economy in that year. The flow of production and consumption benefits accruing to firms and households from the stock of the pure public good was benchmarked to ensure that in equilibrium our simulated city had the same city population as Philadelphia in FY 1998. We chose to benchmark the analysis to city population as the most accurately measured city scalar in FY 1998. Thus $N^{*}+\mathrm{D}$ and $\delta^{*}$ equal, by requirement, the actual values for the city. All other variables in the model are conditional on this selected city size. We find that our simulated city is somewhat smaller economically than the actual city, as estimated (using eq. 15e) from the city's actual gross receipts tax base (X) in FY 1998. Simulated city employment 
Table 3: Model Validation for Philadelphia, FY $1998^{\dagger}$

\begin{tabular}{|c|c|c|c|c|}
\hline \multirow[b]{2}{*}{ City Demographics: } & Variable & Predicted & & Actual $^{\text {t+ }}$ \\
\hline & & & & \\
\hline & $N+D$ & 552,071 & $\equiv$ & 552,071 \\
\hline & $\delta:$ & .32 & $\equiv$ & .32 \\
\hline
\end{tabular}

Firm Production:

$X:$

$N+M:$

$W$ :

$K /(N+M):$

$\left(1+\tau_{m}\right) S m:$

Wn:

$\left(r+\tau_{p}\right)(R / r) \ell_{f}:$
$\$ 22.663$ Billion

530,637

$\$ 29,703 /$ worker

$\$ 75,515$

.322

.492

.050
$\$ 28.545$ Billion

559,200

$\$ 36,871 /$ worker

$(\$ 79,083)$

Household Consumption:

$$
\begin{array}{lll}
(1-\delta)\left(h_{r}+(R / r) \ell_{r}\right) & & \\
+\delta\left(h_{d}+(R / r) \ell_{d}\right): & \$ 78,655 / \text { household } & \$ 49,400 / \text { household } \\
& & \\
(1-\delta) x_{r}+\delta x_{d}: & \$ 17,538 / \text { household } & \$ 18,859 / \text { household }
\end{array}
$$

City Finances:

\begin{tabular}{lrr}
$\tau_{p} B_{p}:$ & $\$ 4,466 /$ household & $\$ 1,226 /$ household \\
$\tau_{s} B_{s}:$ & $\$ 125 /$ household & $\$ 171 /$ household \\
$\tau_{w} B_{w}+\tau_{m} B_{m}:$ & $\$ 1,496 /$ household & $\$ 1,841 /$ household \\
$\tau_{X} B_{X}:$ & $\$ 118 /$ household & $\$ 149 /$ household \\
$\mathcal{R}:$ & $\$ 6,205 /$ household & $\$ 3,387 /$ household \\
\hline
\end{tabular}


Notes for Table 3

${ }^{\dagger}$ All dollar figures are reported in real (1994) dollars.

"Sources for actual Philadelphia or nacional (reponted within (.)) values of each variable.

$N+D:$ City Population (Households): Census Bureau, Web Page: URL:

http: / / www. census . gov/population/www/estimates/popest . html.

\&: Percent Population Who Are Dependenr: $\delta=D /(N+D)$ from the 1990 Census of Popularion and Housing. Summary Tape File: STF3A.

$X$ : Aggregate City Output: Estimated from the reported Gross Receipts Tax Base for Philadelphia, FY 1998, Deparment of Revenue.

$N+M$ : Totah, Non-govermmental City Employment: Bureau of Labor Statistics. State and Area Employment, Web Page: URL: http: / / stats . bls . gov: 80 / sahome . html.

W: Wage of City Workers: 1990 Census of Population and Housing. Summary Tape File: STF3A.

$K /(N+M)$ : Capital to Labor Ratio: Estimated as the national ratio of 1997 non-residential, nonagricultural equipment and structure capital (Survey of Current Business, September. 1998, p. 36; adjusted to 1994 dollars) to non-governmental, non-agricultural employment (Economic Report of the President, 2000. Table B-44).

$\left(1+\tau_{m}\right)$ Sm: Manager Compensation as a Share of Output: The share of 1998 national non-farm. non-governmental income earned by "Managers and Professional Specialists" estimated as the ratio of manager compensation (Statistical Abstract of the United States, 1999. "Earnings of Full-Time Wage and Salary Workers" and "Employee Civilians by Occupation") to National Income earned in non-farm, non-governmental production (Economic Report of the President, 1999, Table B-29).

$W n$ : Worker Compensation as a Share of Outpur: The share of 1998 national non-farm. nongovernmental income earned by workers other than managers estimated as the ratio of non-manager worker compensation (Statistical Abstract of the United States, 1999, "Earnings of Full-Time Wage and Salary Workers" and "Employee Civilians by Occupation") to National Income earned in non-farm, non-governmental production (Economic Report of the President, 1999, Table B-29).

$\left(r+\tau_{p}\right)(R / r) \ell_{f}:$ Rental Income as a Share of Output: The share of 1998 national non-farm. non-governmental income earned as rental income estimated as the ratio of rental income to National Income earned in non-farm, non-governmental production (Economic Report of the President, 1999, Table B-29).

$(1-\delta)\left(h_{r}+(R / r) \ell_{r}\right)$

$+\delta\left(h_{d}+(R / r) \ell_{d}\right)$ : Median Home Value: 1990 Census of Population, Summary Tape File: STF1A.

$(1-\delta) x_{r}+\delta x_{d}$ : Consumption per Household: Estimated as median household income in Philadelphia (1990 Census of Population, Summary Tape File: STF1A) minus actual tax revenues per household minus .05 . Median home value $=\$ 24,716-\$ 3,387-\$ 2,470=\$ 18,859$.

$\tau_{p} B_{p}:$ Property Tax Revenues per Household: City and school district property tax revenues (FY 1998, Department of Revenues, Philadelphia, PA) divided by number of households (see $N+D$, above).

$\tau_{s} B_{s}:$ Sales Tax Revenues per Household: City sales tax revenues (FY 1998. Department of Revenues. Philadelphia. PA) divided by number of households (see $N+D$, above).

$\tau_{w} B_{w}+\tau_{m} B_{m}$ : Wage Tax Revenues per Household: City wage tax revenues (FY 1998. Department of Revenues. Philadelphia. PA) divided by number of households (see $N \div D$, above).

zX B $B_{Y}:$ Gross Receipts Tar Revenues per Household: City gross receipts tax revenues (FY 1998, Department of Revenues, Philadeiphia. PA) divided by number of households ( see $N+D$, above).

R: Total Tar Revenues per Household: Total city and school district tax revenues (FY 1998, Department of Revenues. Philadelphia. PA) divided by number of households ( see $N+D$. above). 
$\left(N^{*}+M^{*}\right)$ is also less than actual city employment $(\mathrm{N}+\mathrm{M})$, either because the simulated city hires fewer commuter-managers than does the actual city or because some of the city's actual resident-worker households provide more than one worker per household as we assume in the model. The simulated production sector uses approximately the same capital to labor ratio and yields very similar pre-tax factor shares for private goods inputs as does the U.S. national economy; Philadelphia data for these variables are not available. The model's simulated wage for resident workers $\left(W^{*}\right)$ is somewhat lower than the actual average wage for city residents who work. Predicted average consumption by residents $\left(x .^{*}=\left(1-\delta^{*}\right) \cdot x_{r}^{*}+\delta^{*} \cdot x_{\phi}\right)$ is also somewhat lower than the consumption for an Philadelphia family with the city's median (and therefore average) income. Average home values for residents $\left(h .^{*}=\left(1-\delta^{*}\right)\left[h_{r}^{*}+(R / r) \ell_{r}^{*}\right]\right.$ $\left.+\delta^{*}\left[h_{d}^{*}+(R / \mathrm{r}) \ell_{d}^{*}\right]\right)$ in our simulated economy are approximately 1.5 times as high as the 1990 median city home value, however. ${ }^{16}$ This result plus the fact that our simulations make no allowances for the tax-exempt status of the city's non-profit employers (e.g., universities and hospitals) and for tax abatements for business property also mean that simulated property taxes

${ }_{16}$ There are three possible reasons for our overestimate. First, the 1990 median home value may significantly underestimate true average city home value because of positive skewness in the distribution of housing values. Second, Philadelphia housing values today may exceed values in the 1990 Census because homes have appreciated in value over the intervening years. Philadelphia Magazine's annually comparison of Philadelphia metropolitan housing values based on area housing sales estimates the average value of Philadelphia city homes has risen by about 20\% since 1990; Philadelphia Magazine, April, 2000 , p. 89 . Third, our model makes no allowances for neighborhood amenities unrelated to public goods or market job opportunities. To the extent Philadelphia's neighborhoods are differentially less attractive than elsewhere, actual values will be lower than our simulated values. 
per household are significantly higher than the city's actual property tax revenues per household. ${ }^{17}$ Our model's estimates of the other tax revenues per household are smaller than actual values because of the smaller size of our simulated economy, falling short by about $20 \%$, approximately equal to our underestimate of the size of the city's true aggregate economy.

We offer three further comparisons as tests for the plausibility of our simulation model of the Philadelphia public economy. First, in previous work (Haughwout, Inman, Craig, and Luce, 2000) we estimated the elasticity of Philadelphia tax bases to changes in city tax rates for the three taxes for which sufficient time series data (FY 1970-1998) were available: property taxation, combined resident and non-resident wage taxation, and gross receipts taxation. ${ }^{18}$ The econometrically estimated tax base elasticities evaluated at FY 1998 rates are reported in Table 4 along with the simulated tax base elasticities for the same three taxes calculated from the FY 1998 parameterization of the Philadelphia economy. With the exception of the own elasticity for the gross receipts tax base $\left(\varepsilon_{\mathrm{Bx}, \mathrm{Tx}}=-.39\right.$ (estimated) vs. -.03 (simulated)), all of the simulated elasticities are more negative (base more responsive) than their econometrically

17 If differences between simulated and actual property tax bases only reflected differences in average home values (see Table 3), then we would expect simulated property tax revenues to be approximately twice actual revenues. In fact, simulated revenues are four times larger than actual revenues. This can only mean that the other components of the property tax base -- taxable commercial-industrial property -- is much less in the real Philadelphia economy than in our simulated economy, most likely because of significant tax relief for the city's commercial-industrial sector. Also likely to be important is the fact that Philadelphia has large non-profit and government sectors which are excluded from the city's actual property tax base, but which are included as part of our simulation model's "private economy".

18 Philadelphia resident and non-resident wage tax rates moved together for most of the sample period so separate resident and non-resident base elasticities could not be identified; see Haughwout, et. al. (2000). Further, the city sales tax had only one rate change over the sample period, so again, no base elasticity could be estimated for this tax. 


\title{
Table 4: Tax Base Elasticities: Estimated vs. Simulated
}

\author{
Elasticities of Tax Base with Respect to Tax Rates: Estimated ${ }^{\dagger}$
}

\begin{tabular}{|c|c|c|c|}
\hline & $B_{p}$ & $B_{X}$ & $\underline{B_{w+m}}$ \\
\hline$\tau_{p}$ & $\begin{array}{r}-.57 \\
(.11)\end{array}$ & $\begin{array}{c}.17 \\
(.13)\end{array}$ & $\begin{array}{r}-.06 \\
(.06)\end{array}$ \\
\hline$\tau_{X}$ & $\begin{array}{c}.06 \\
(.05)\end{array}$ & $\begin{array}{c}-.39 \\
(.06)\end{array}$ & $\begin{array}{c}.01 \\
(.03)\end{array}$ \\
\hline$\tau_{w+m}$ & $\begin{array}{c}.38 \\
(.21)\end{array}$ & $\begin{array}{c}.14 \\
(.25)\end{array}$ & $\begin{array}{c}-.04 \\
(.12)\end{array}$ \\
\hline
\end{tabular}

Elasticities of Tax Base with Respect to Tax Rates: Simulated ${ }^{\text {t+ }}$

$\begin{array}{llll} & \frac{B_{p}}{\tau_{p}} & \frac{B_{X}}{\tau_{p}} & \frac{B_{w+m}}{-.73} \\ \tau_{X} & -.82 & -.73 & -.74 \\ \tau_{w+m} & -.26 & -.03 & -.03 \\ & & -.33 & -.34\end{array}$

${ }^{\dagger}$ From Haughwout, Inman, Craig, and Luce (2000), Table 3. Estimates are based on small changes in tax rates from FY 1998 actual values. Standard errors are in parentheses.

"Tax base elasticities for the simulated economy were estimated for small changes in tax rates from the FY 1998 actual values, holding all other rates fixed ar FY 1998 values. 
estimated counterparts, most of which are not statistically significantly different from zero. This is due in part to the fact that the simulated elasticities are equilibrium responses, while the estimated elasticities -- for reasons of data limitations -- only measure the one-year impact effect of rate changes on base. Haughwout, et. al., were able to estimate a longer-run (four year) elasticity for property tax base with respect to its own rate only, and this estimated elasticity equaled $-.76(s . e .=.24)$, close to the simulated long-run elasticity. Also contributing to the lower estimated elasticities, particularly for the effect of $\tau_{\mathrm{p}}$ on $\mathrm{B}_{\mathrm{x}}$ and $\mathrm{B}_{\mathrm{w}+\mathrm{m}}$, is the apparent under-taxation of commercial-industrial property in the real Philadelphia economy because of exemptions and abatements. ${ }^{19}$

As a second point of comparison, Figure 2 illustrates Philadelphia's estimated revenue hills for FY 1998 from Haughwout, et. al. (2000), shown as dashed lines over the range of tax rates for the FY 1970-1998 sample period, as well as our model's simulated revenue hills for the same tax bases, shown as solid lines. At least over the relevant sample ranges, our simulated and estimated revenue hills are similar in shape and, with the exception of the city's property tax for reasons noted above (footnote 17), raise approximately the same levels of city revenues.

Third, we can compare the simulated effects of Philadelphia taxes on city jobs with the econometrically estimated elasticities obtained in Haughwout, et. al. (2000) computed at FY 1998 rates; see Table 5 (simulated population elasticities are also reported). The estimated

${ }^{19}$ Empirical mis-specification could also drive a wedge between the econometrically estimated and simulated elasticities, though Haughwout, et. al. (2000) did conduct several sensitivity tests to explore this possibility. The results reported in Table 4 were generally robust to these specification changes. 


\section{Simulated and Estimated Revenue Hills Philadelphia, 1998*}

\section{Property Tax}

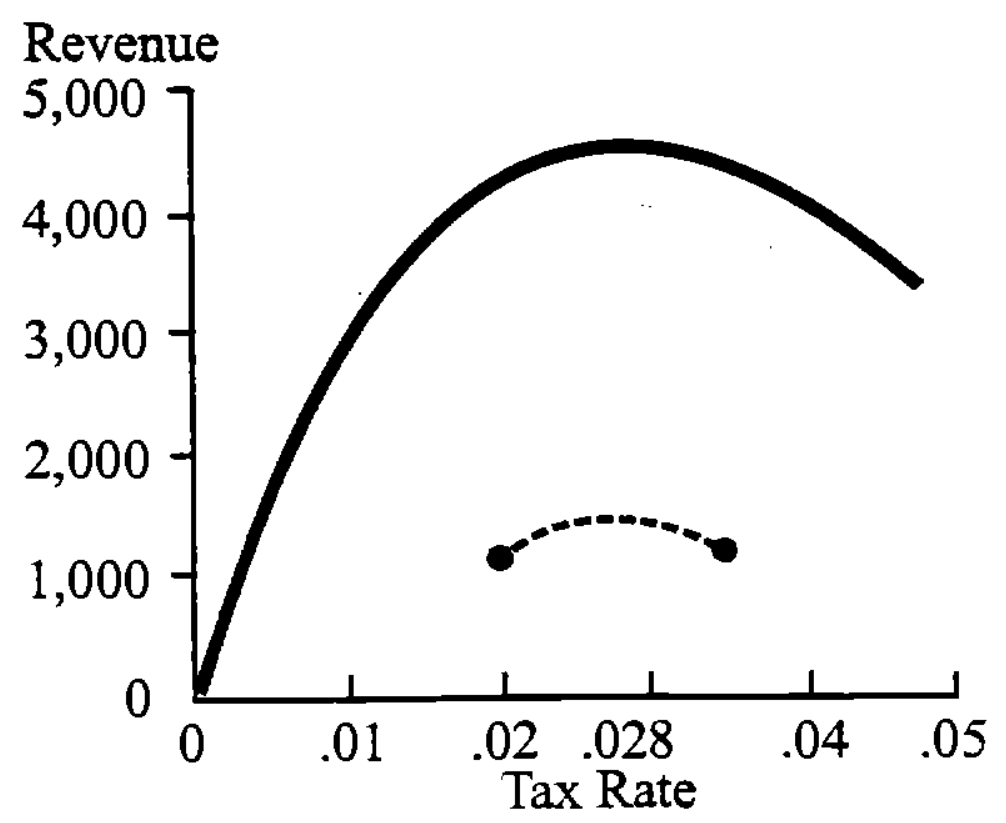

\section{Resident Plus Non-Resident Wage Tax**}

Revenue

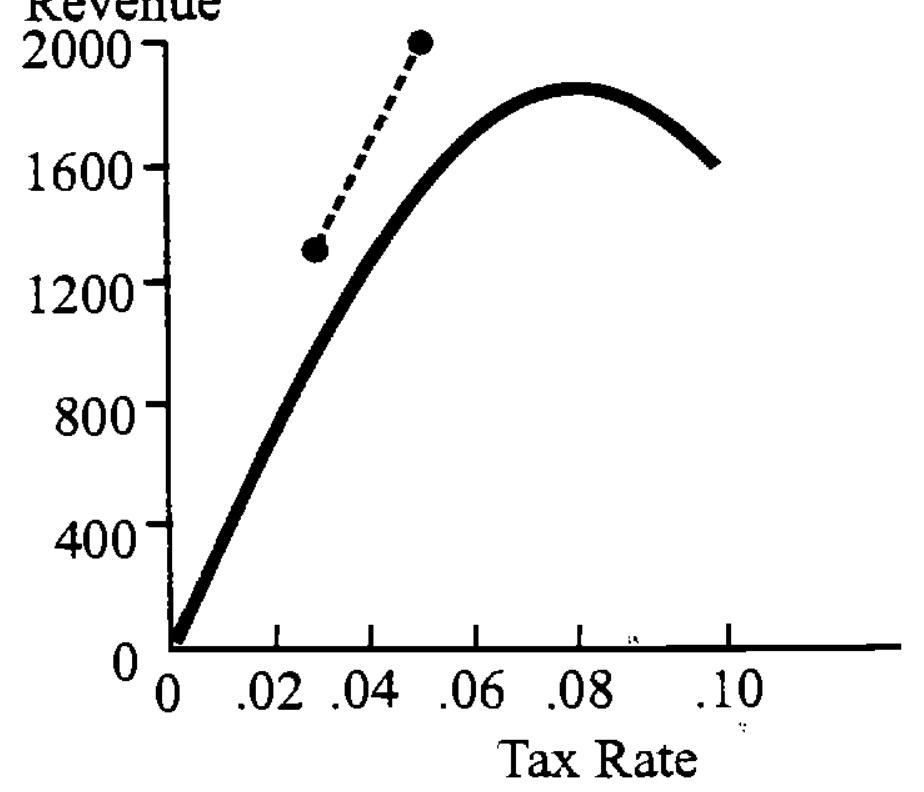

Gross Receipts Tax

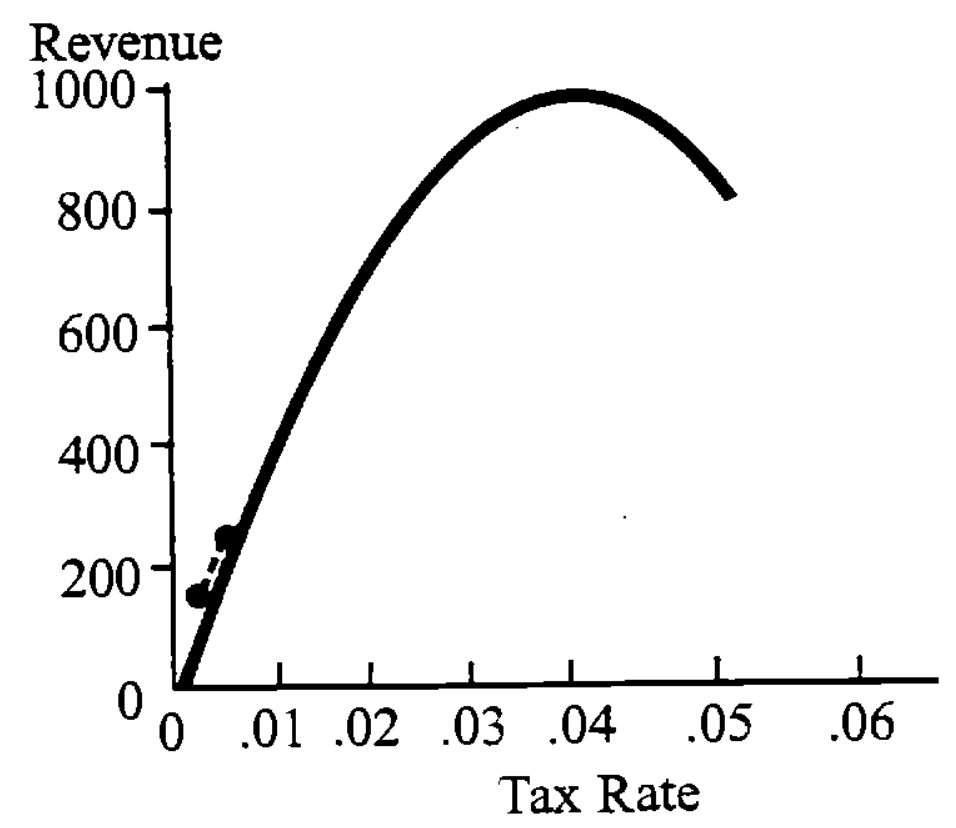

* All simulated revenue hills are represented by solid lines, while estimated hills are represented by dashed lines between the sample range of actual city tax rates. Simulated and estimated revenue hills are for FY 1998, holding all other local tax rates fixed at FY 1998 values. Revenues are in 1994 dollars per bousehold.

**Simulated and acrual hills for joint changes in resident and non-resident tax rates are for equal percentage changes in both tax rates from their FY 1998 values. The weighted average of residential and non-residential zates is shown in Figure? 
Table 5: Job and Population Tax Elasticities: Simulated Economy ${ }^{\dagger}$

\begin{tabular}{lcccccc} 
& \multicolumn{6}{c}{ Elasticity with Respect to: } \\
\cline { 2 - 7 } & $\tau_{p}$ & $\tau_{w}$ & $\tau_{m}$ & $\tau_{w+m}$ & $\tau_{s}$ & $\tau_{X}$ \\
\hline Jobs $(N+M)$ & -2.69 & -.66 & -.80 & -.70 & -.23 & -.11 \\
& $(.06)$ & $(.03)$ & $(.07)$ & $(.04)$ & $(.04)$ & $(.02)$ \\
Population $(N+D)$ & -1.49 & -.51 & -.62 & -.54 & -.17 & -.07 \\
& $(.01)$ & $(.02)$ & $(.05)$ & $(.02)$ & $(.02)$ & $(.01)$ \\
\hline
\end{tabular}

${ }^{\dagger}$ All estimated elasticities are average (log-log) elasticities of jobs or population with respect to changes in local tax rates. holding all other city tax rates at their FY 1998 values (see Table 1). Standard errors from the log-log regression are reported within parentheses. 
elasticity of Philadelphia jobs $(N+M)$ to changes in the city's weighted average of resident and non-resident wage tax rates $\left(\tau_{w+m}\right)$, evaluated at FY 1998 rates, equaled $-.54(s . e .=.12)$ for all jobs and $-.78($ s.e. $=.25)$ for manufacturing jobs only, both plausibly close to the simulated job elasticity of -.70 . The econometrically estimated elasticity of city jobs with respect to the city property tax was $-.20($ s.e. $=.14)$; in contrast, in the simulated economy the elasticity of jobs with respect to $\tau_{\mathrm{p}}$ is -2.69 (Table 5). Again we suspect the large differences here can be explained by the fact that the econometric estimates are impact elasticities while the simulated elasticities measure equilibrium responses and the fact that the firms in our simulated economy are assumed to bear their full share of city property taxation while in the actual Philadelphia economy firm capital apparently receives extensive tax exemptions and abatements. Haughwout et. al.'s estimate for the elasticity of jobs with respect to the city's gross receipts tax rate is also low, -.063 (s.e. $=.048)$, and not statistically different from zero; here, however, the estimated elasticity compares favorably with the relatively low elasticity from the simulated economy. ${ }^{20}$

\section{Fiscal Policy in an Open City Economy: Philadelphia, FY 1998}

Figure 3 illustrates the revenue potential inherent in the five taxes available to the city of Philadelphia, calibrated to FY 1998. The city has direct control over only two of these local taxes, the property tax and the gross receipts tax; the equilibrium revenue hill for these two locally-controlled taxes is shown in the top panel of Figure 3. The bottom three panels of

20 Finally, the results presented here for the simulated Philadelphia economy are consistent with the existing theoretical literature on the general equilibrium effects of local taxes on the local private economy in small open cities. As in Polinksy and Rubinfeld (1978), Arnott and McKinnon.(1977), Brueckner (1982), and Sullivan (1985) land values fall, wages rise, housing consumption falls, city production falls, and immobile residents' utility declines as the property tax rate is increased. 
Figure 3

\section{Projected Philadelphia Revenues FY 1998*}
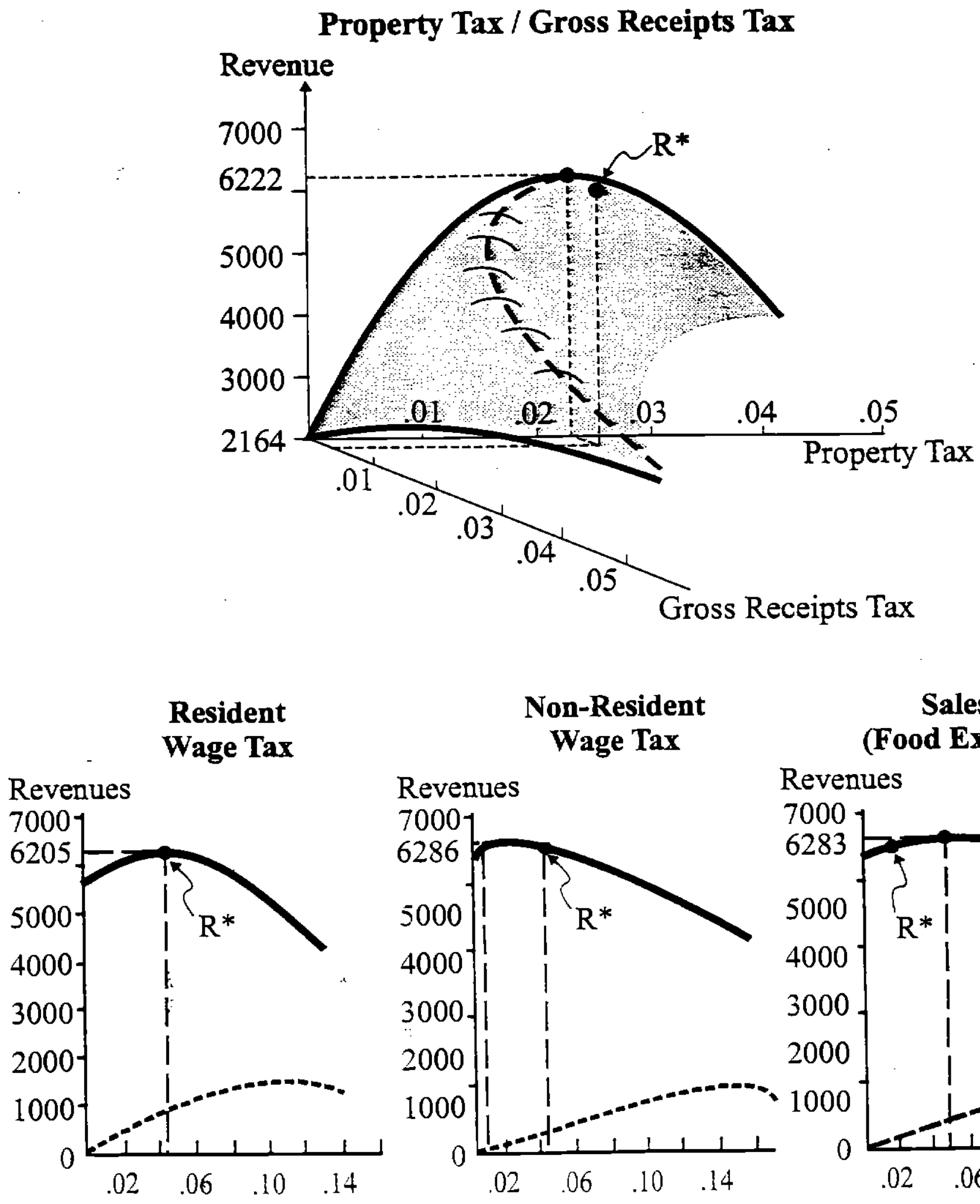
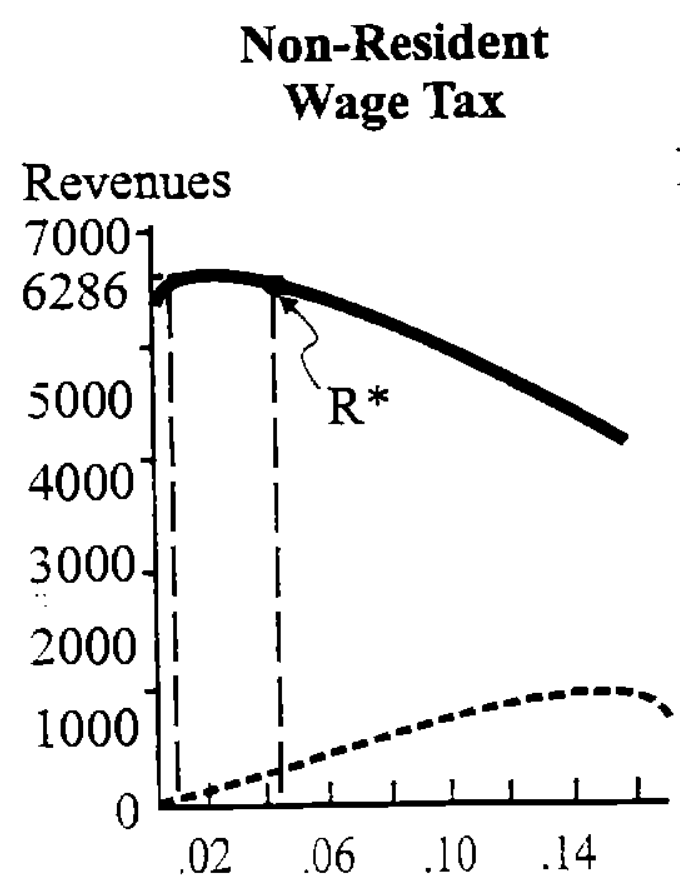

Sales Tax

(Food Exemption)

Revenues

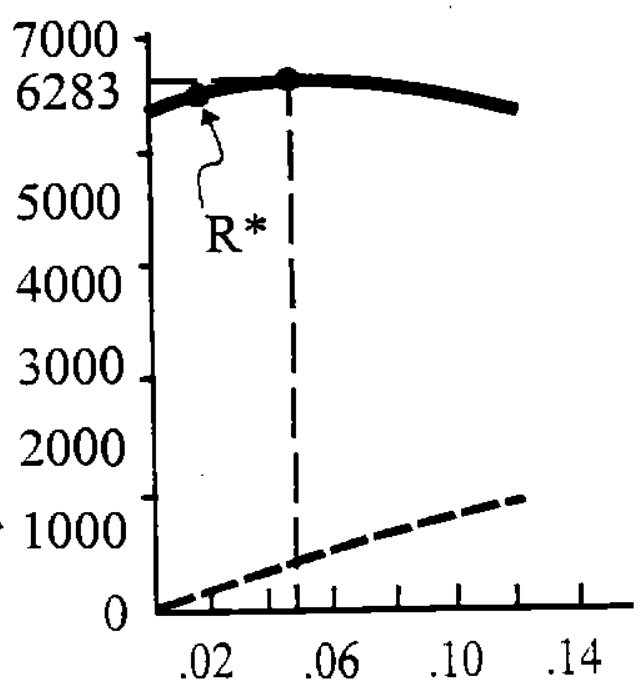

* Simulated revenue hills are for FY 1998. Revenues are in 1994 dollars per household. 
Figure 3 illustrate the revenue that can be raised from each of the three state regulated tax rates for resident, non-resident, and general sales taxation, respectively. Because a change in any one city tax rate has effects on all city tax bases (see Table 4), the revenue potential of each tax must be measured through total city revenues, not just own tax revenues. Figure 3 therefore shows total city revenues resulting from each tax rate or combination of rates, holding all other tax rates fixed at their FY 1998 values. When rates equal their FY 1998 values, total city revenues equal $\$ 6205 /$ household, the level of equilibrium total revenues ( $\Re *$; Table 2$)$ from our status quo simulation.

Holding the three regulated city tax rates at their current FY 1998 values, the top panel of Figure 3 shows how much additional revenues Philadelphia might be able to raise by adjusting its two discretionary local tax rates from their FY 1998 status quo values of $\tau_{\mathrm{p}}=.0249$ and $\tau_{\mathrm{X}}$ $=.002875$. The peak of the revenue hill for discretionary taxes occurs at $\tau_{\mathrm{p}}{ }^{\max }=.0245$ and $\tau_{\mathrm{X}}^{\max }=.00$ and earns the city a maximum revenue of $\$ 6222 /$ household, an increase of only $\$ 17 /$ household above actual FY 1998 revenues $\left(\Re^{*}=\$ 6205 /\right.$ household $)$. Interestingly, discontinuing the use of the gross receipts tax actually improves city revenues per household. As $\tau_{\mathrm{X}}$ falls towards zero, economic activity within the city, all other tax bases, and thus all other tax revenues increase by more than enough to compensate for the loss in gross receipts revenues. ${ }^{21}$ The lower three panels of Figure 3 illustrate the revenue potential of raising each of the regulated city tax rates, one at a time. Again the simulations hold all other local tax rates fixed at their current FY 1998 levels. In each of the lower panels we show two hills: one for

${ }^{21}$ As the city "walks up the hill" along the ray at $\tau_{\mathrm{p}}=.0245$ by lowering $\tau_{\mathrm{X}}, X^{*}$ rises; for example, at $\tau_{\mathrm{X}}=.045, X^{*}=\$ 6.0$ billion; at $\tau_{\mathrm{X}}=.0125, X^{*}=\$ 17.386$ billion; and at $\tau_{X}=.00, X^{*}=\$ 25.700$ billion. 
total city revenues per household (solid line) and another for own revenues per household (dashed line). The difference between the two revenue paths represents the effects on the other tax bases of increasing each regulated tax rate. ${ }^{22}$ At the peak of each of the total (solid line) city revenue hills, the increase in own revenues just equals the fall in other revenues; beyond the peak, the fall in other revenues dominates the rise in own revenues and total city revenues per household decline. Again, Philadelphia appears very near the peak of each of the per household total revenue hill for its three regulated taxes. Small ceteris paribus changes in the resident wage tax rate will raise no additional monies. Lowering the non-resident wage tax rate will increase total city revenues per household by $\$ 81 /$ household ( $=\$ 6286 /$ household $\$ 6205 /$ household), again because the aggregate economy expands as tax rates declines. Finally, raising the sales tax rate from $\tau_{\mathrm{s}}=.007$ to $\tau_{\mathrm{s}}=.042$ increases total revenues $\$ 78 /$ household (=\$6283/household $-\$ 6205 /$ household). No matter in which direction the city moves from its FY 1998 status quo equilibrium, the simulated Philadelphia economy appears to be able to generate no more than $1.3 \%$ ( $\$ 80 /$ household) in new revenues. To the extent our simulated economy is a valid representation of the actual city economy, we conclude that Philadelphia is at, or very close to, the peak of its long-run revenue hill.

The results in the lower panel of Figure 3 for the three regulated taxes are instructive for a second issue of importance for Philadelphia fiscal policy: Why does the state of Pennsylvania

22 Since an increase in any one city tax rate tends to lower all other tax bases (see Table 4), revenues per household from other taxes declines. This need not always happen; if population falls faster than the fall in investment, consumption, or employment, then revenues per household could rise. Because of the significant number of immobile, dependent households within Philadelphia, however, base per household always falls as rates increase in our simulated economy. 
regulate city wage and sales tax rates? A comparison of each regulated tax's own revenue hill (dashed lines) with the tax's effect on total revenues (solid lines) shows that while own revenues/household are nearly always rising, total revenues/household peak at relatively low tax rates. The reason, as noted, are the important general equilibrium effects of each tax rate on the city's other tax bases; see Table 4. If these general equilibrium effects which reduce total city revenues/household unfold only slowly, however, rising own revenues may dominate total revenues for the first years after the increase in local rates. If the equilibrium adjustment process takes long enough, local revenue policies may fall prey to the problem of time inconsistent preferences. Current city politicians may raise rates and own revenues during their term in office, but leave future politicians with absolutely lower total city revenues after all equilibrium adjustments have taken place. If so, the city can be in a political equilibrium permanently beyond the peak of their equilibrium total revenue hill, an unambiguously inefficient allocation; see Inman (1989). One solution is to regulate local tax rates, as the state of Pennsylvania has in fact done.

Time inconsistency aside, there are two additional reasons why Pennsylvania might wish to regulate Philadelphia wage and sales taxes. ${ }^{23}$ Table 6 shows what happens to the city's private $\left(X^{*}, N^{*}, M^{*}, \delta^{*}, W^{*}, R^{*}\right)$ and public $\left(G^{*}\right)$ economies as well as to the welfare of the city's poor and elderly dependent households $\left(V_{d}{ }^{*}\right)$ as each of the three regulated tax rates are increased. As these tax rates rise, both the private and public economies get smaller. Output

${ }^{23}$ Haughwout, et. al. (2000) present tentative evidence for four large U.S. cities including Philadelphia that the response of local taxes bases, at least with respect to changes in own tax rates, occurs reasonably quickly, typically within 2 to 3 fiscal years. This suggests that the time inconsistency problem may not be the whole story behind state regulation. 


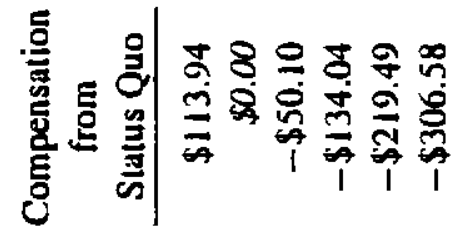

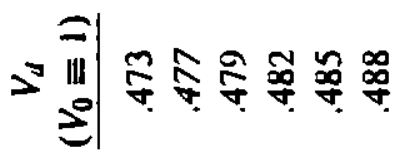

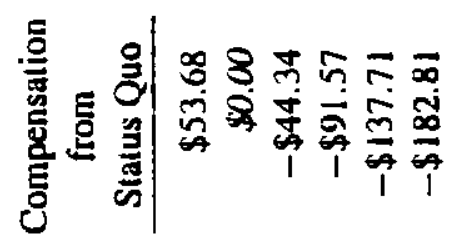

>

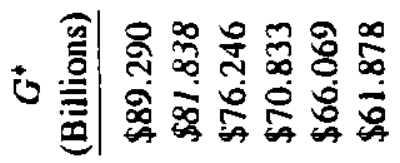

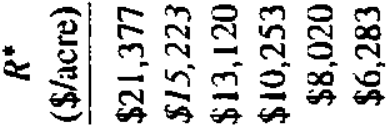

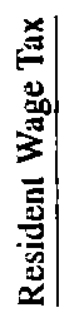

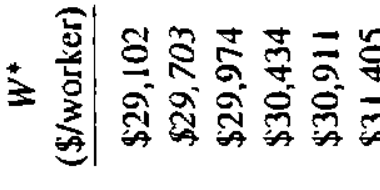

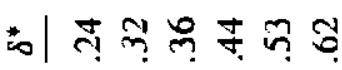

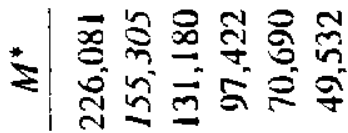

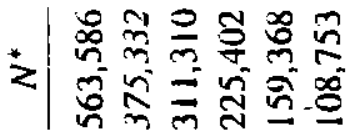

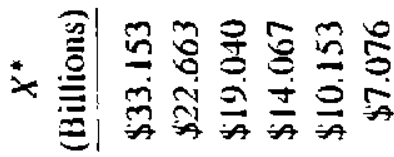

ง|

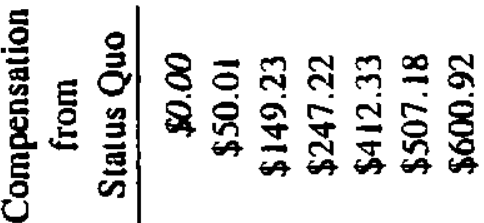

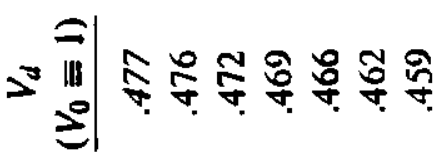

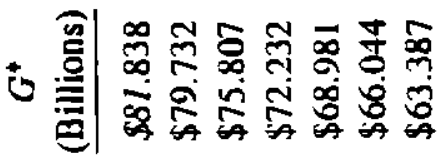

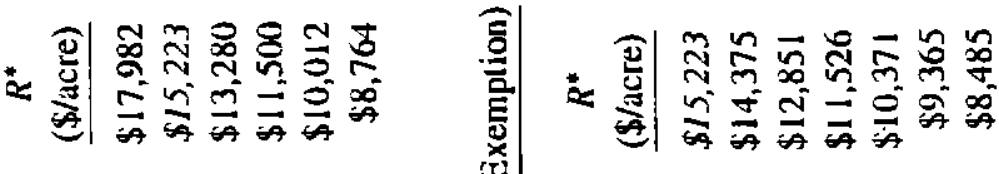

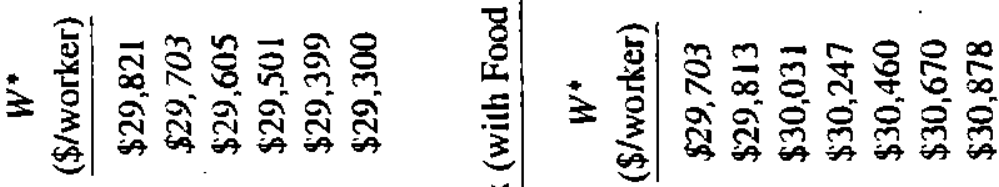

*

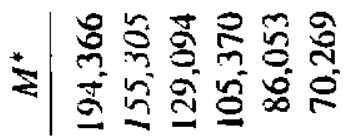

* กิ

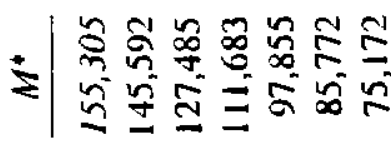

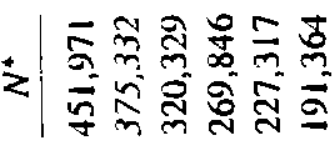

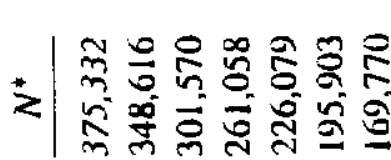

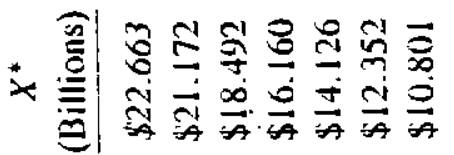

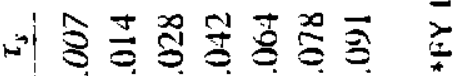


declines, employment and total population fall, and the stock of the pure public good declines. ${ }^{24}$ The fall in the number of resident households means the percent of residents who are dependent ( $\delta)$ rises, and indeed, when rates are high enough, the dependent population becomes a local majority (or nearly so). Note too that for both wage taxes, the utility of the typical dependent household rises. This makes sense as dependent households do not pay these taxes. While dependent households bear a burden through the fall in the valued public good $\left(G^{*}\right)$, they are more than compensated by a lower cost of housing because of the equilibrium fall in city rents, $R^{*}$. Thus $\mathrm{V}_{\mathrm{d}}{ }^{*}$ rises. What the Table 6 results imply is that dependent households have an incentive to capture the local political process, raise wage tax rates, and drive out the middle class. In the process, their political coalition becomes more important and their utility rises. One measure of this incentive to capture politics is shown in Table 6 as "Compensation from the Status Quo" measuring the amount of money which must be paid to $(+)$, or would be paid by $(-)$, a single dependent household for a move from the status quo tax rate (shown in italics) to each of the new tax rates. Viewed as political contributions, these payments by dependent households (= (-) "Compensation" in Table 6) may be enough to elect a sympathetic city mayor. The end result will be an economically emaciated center city. State regulation may then be needed to check this politically chosen, but possibly inefficient, outcome. ${ }^{25}$

24 The fall in $G^{*}$ occurs even though revenues per household rise over a range of rate increases. The reason is that while revenues per household rise, the number of households declines at a faster rate, and thus total revenues decline. With the fall in total revenues, total expenditures on the pure public good must fall as well. Thus $G^{*}$ falls.

25 The analysis here is at best suggestive. For this argument to offer a compelling case for state regulation we will need at least three additional assumptions, none of which is formally included in our model. First, the need for regulation assumes having a smaller city imposes real economic costs on the larger society. This could occur if the larger city 
The results in Table 6 raise the possibility of exactly the opposite incentives when setting the local sales tax rate. Here politics seems likely to drive the city sales tax rate to zero. First, dependent household welfare declines as city sales tax rates increase. As $\tau_{\mathrm{s}}$ rises, $R^{*}$ again declines. While this helps dependent households, the fall in $G^{*}$ and now the rise in the price of private good consumption $\left(1+\tau_{\mathrm{s}}\right)$ both reduce dependent household welfare; on balance, $V_{\mathrm{d}}{ }^{*}$ falls as $\tau_{\mathrm{s}}$ rises. The resident middle class also loses with the rise in $\tau_{\mathrm{s}}$ from the status quo. While their annual utility position is protected by their option to exit the city $\left(V_{0} \equiv 1\right)$, current resident-workers suffer capital losses on the value of their city home since city rents fall as $\tau_{\mathrm{s}}$ rises. Thus no one in the city wishes to use the sales tax. Yet a broad-based sales or consumption tax may be useful source of public revenues, provided all cities raise rates

provides valued private sector agglomeration economies. Note that having a pure public good in cities is not enough to make the case for regulation. Even though the exit of residents raises the average costs of providing public services in our central city, those residents exit to other cities lowering the average costs of public services elsewhere. Second, in making our argument we implicitly ignored the effect of changes in rents on the value of assets owned by dependent households. In our model, dependent households do own land. When we recognize fact that dependent household assets have lost value and then balance the resulting income loss of this decline $\left(\Delta \mathrm{R}^{*} \cdot \ell_{\mathrm{d}}\right)$ against the income equivalent welfare gains reported in Table 6 , the two just about cancel. Our argument only really holds for renters, or elderly who plan for no bequests. These households are not formally in our model.

Third, if assume dependent households are politically active (make campaign contributions), then we must allow the current middle class households to be active too. How much will they contribute to lower tax rates from the status quo? Since their utility is guaranteed by their "exit" option $\left(\mathrm{V}_{0} \equiv 1\right)$, they are only affected by capital gains or losses. In fact as wage tax rates rise, these capital losses $\left(\Delta R^{*} \cdot \ell_{\mathrm{r}}\right)$ experienced by a typical middle class resident household exceed the compensation value of the welfare gains of each (renter) dependent household; further, at the current status quo there are more middle-class households than dependent households. Thus from the status quo, if a poor/elderly coalition seeks to "buy" the favor of local politicians, a coalition of middle class households can offer more. One needs a clear theory of why the poor are well-organized and middle class residents are not, before we can use the results in Table 6 as evidence of a political "market failure" in need of regulation. 
simultaneously. If so, state or national regulation (i.e., policy coordination) of local sales taxation, or perhaps a nationaily-imposed tax with the proceeds distributed to localities, will be needed. ${ }^{26}$

Our analysis here provides insight into a third issue of importance for the financing of local governments, particularly so for U.S. cities in the current climate favoring policy decentralization. The U.S. Welfare Reform Act of 1996 shifts financial responsibility for redistribution policy for low income households from the federal to the state and local level of government. Because in many states, politics favor rural and suburban residents -- Pennsylvania is arguably such a state -- cities may be required to shoulder a growing share of the costs of low income assistance. Table 7 helps us to understand what might happen to the city's private and public economies with such a mandate. The first column in Table 7 defines a "mandated" city share $(\psi)$ for funding the federally established transfer per dependent household of $Y=\$ 13,500$; currently, Philadelphia is estimated to pay a .095 share of this required transfer. Increasing this mandated share, holding all city tax rates fixed at their FY 1998 levels, means a fall in the stock of public goods which can be financed by the city. ${ }^{27}$ The fall in the stock of public goods

26 Again, the argument here turns on an analysis beyond our current model. To make the case for a broad-based consumption tax one needs a dynamic model with savings and economic growth; see for example, Summers (1981) and Judd (1999). The case for coordinated fiscal policy requires a model with other, competitive governments; see for example, Mintz and Tulkens (1986).

27 The Welfare Reform Act of 1996 did include a comfortable financial "cushion" for state and local governments in the form of federal Temporary Assistance for Needy Families (TANF) grants. These grants are given to the U.S. states to replace previous federal matching assistance. To the extent the monies are shared with local governments through an increase in $\mathrm{Z}$ aid, the adverse consequences on $\mathrm{G}^{*}$ of an increase in the mandated local share $(\psi)$ will be softened; see equation 14 . 


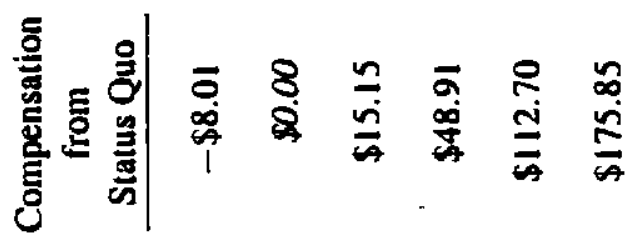

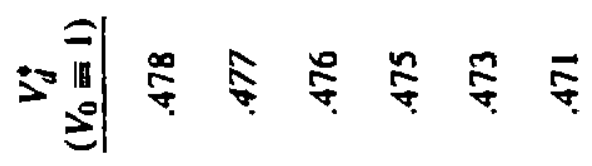

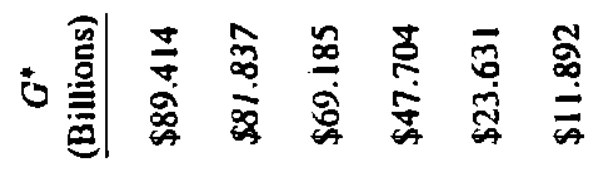

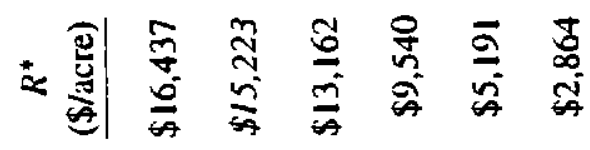

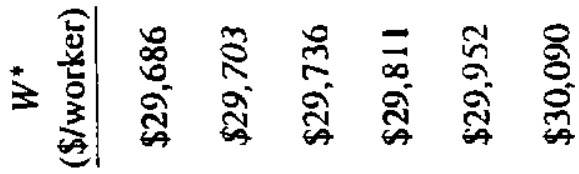

$$
\begin{aligned}
& \text { *1 ๗ }
\end{aligned}
$$

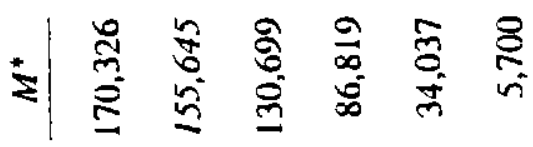

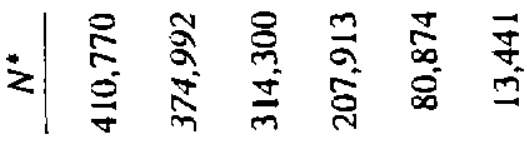

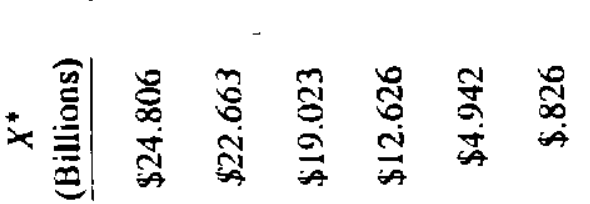

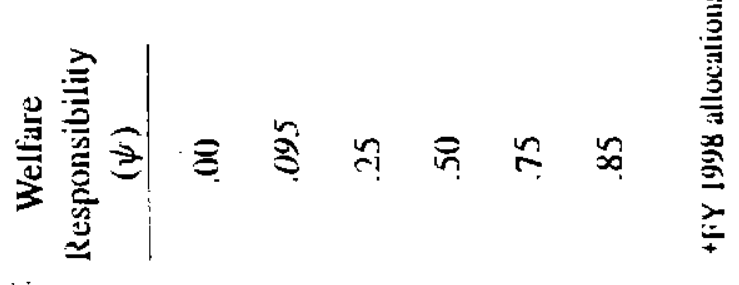


means the city is less attractive for middle class households and firms. They exit, lowering $X^{*}$, $N^{*}, M^{*}$, and $R^{*} ; W^{*}$ rises slightly as compensation for resident-workers who do stay in the city. The shrinking city economy means a much smaller tax base, both per household and in the aggregate. Thus $G^{*}$ must fall. The results in Table 7 show just how sensitive the city's economy is to fiscal policies, such as a rising $\psi$, which raise taxes and do not provide compensating public services. For example, increasing the city's responsibility for dependent household transfers from its current share $(\psi)$ of .095 to .25 -- certainly a possible outcome under the new structure for financing U.S. welfare -- will shrink both the city's private economy $\left(X^{*}, N^{*}+M^{*}, R^{*}\right)$ and public economy $\left(G^{*}\right)$ by about 15 percent. Once the local share of the mandated redistribution $(\psi)$ exceeds .85 , the city is no longer a viable economic center. As $\psi$ rises, the dependent households left behind see their welfare $\left(V_{d}^{*}\right)$ fall, even though their level of transfer income remains protected at $\$ 13,500$.

Dependent households might take a more active stance as $\psi$ rises, and offer some of their transfer income to help pay for the new mandate; they could do so by accepting a lower value of Y. An approximation to the maximal reduction in $\mathrm{Y}$ that each dependent household might offer is the value of the compensation needed to make them whole after each increase in $\psi$; see Table 7, "Compensation from Status Quo." ${ }^{28}$ Unfortunately, these available offers from the dependent poor are much too small to cover the added costs to the city from increasing $\psi$; for

${ }^{28}$ Strictly speaking we should calculate the dependent household's willingness to pay to move from a new value of $\psi$ (say, $\psi=.25$ ) back to the original value of $\psi=.095$. In fact, the welfare estimates in Table 7 measure how much we must compensate the dependent household to accept the move from $\psi=.095$ to the new $\psi$. Because of income effects, the typical dependent household's willingness to pay will not be equal to its required compensation. The differences in this case will be trivial, however, and will make no difference for our conclusions above. 
example, for $\psi=.25$ the city must spend $\$ 2092$ more per poor household $(=\$ 2092=[.25$ $.095] \$ 13,500$ ) while a typical poor household will contribute at most $\$ 15.15$. Rising federal or state mandates for city financing of low income households will necessarily impose a tax burden on middle class households and firms and a welfare loss on the city's poor. Suburban and rural residents gain through lower federal and state taxes. ${ }^{29}$

\section{Conclusion}

The move towards increasing fiscal decentralization, both in the United States and internationally, has given new urgency to the need to understand the economic consequences of fiscal policies in open city and regional economies. This paper has offered a general equilibrium model of an open city with both mobile firms and resident-workers to examine the consequences of alternative local and national fiscal policies on the equilibrium prospects of the city's private and public economies. Given household preferences and firm technologies and an exogenous configuration of city tax rates and national grants and fiscal mandates, the model calculates equilibrium values for firm production and input use, household consumption and housing choices, city wages, rents, and population, and finally, local tax bases, revenues, and public goods provision.

The analytic approach outlined here is useful for at least two methodological reasons. First, for given firm technologies and household preferences, the model itself helps us to understand the equilibrium consequences of changes in initial demographics, and exogenous

29 See Baicker (1999) for a careful analysis of the incidence of federal mandates on state and local governments. Her econometric results are consistent with the results obtained here from our simulation model. 
fiscal institutions and policies on private economic performance, changes not easily understood without a fully specified market model with mobile firms and households. Second, the model offers an important complementary tool to the usual econometric approach to studying how local fiscal policies impact on the private sector in open economies; see Bartik (1991) for a review of the empirical evidence. When calibrated to a real city economy -- here, Philadelphia -- our model provides an important benchmark against which to judge the plausibility of econometric estimates of the effects of fiscal policy, estimates often plagued by bias from the likely simultaneity of private choices and government policies. Alternatively, econometric estimates which successfully control for the endogeneity of fiscal policy permit a finer calibration of the simulation model. Both approaches, simulation and estimation, are valid tools for understanding how a city's private economy responds to fiscal policy.

Once calibrated and validated, our model allows us to examine the economic consequences of alternative policy regimes. Three issues of current concern to our sample city, Philadelphia, were examined here. First, can the city raise additional revenues through adjustments in its local tax rates? To the extent that Figure 3 accurately represents the city's revenue potential, the answer appears to be No. Philadelphia's current rate structure has moved the city very close to the top of its total revenue hill -- in fact, it is slightly over the top of the hill for its discretionary taxes. The city can raise at most 1.3 percent additional revenues through adjustments in local tax rates -- by lowering property, gross receipts, and non-resident wage tax rates, and/or by raising the local sales tax rate; see Figure $3 .^{30}$ Second, Philadelphia

30 There is an important caveat to this conclusion and that is the apparent significant tax exemptions and abatements now available to firm capital in Philadelphia's actual tax structure; see footnote 17 above. These exemptions for firm capital are not included in our 
wage and sales tax rates are regulated by the state; Is this valid? The analysis here cannot answer this question definitively, but our results are suggestive of three reasons for concern that the city might mismanage these two taxes: time inconsistency (both wage and sales taxes), local politics favoring redistribution towards the city's immobile households (wage taxation), and a race-to-the-bottom competition with other communities (sales taxation); see Figure 3 and Table 6. Third, in this new era of fiscal decentralization, can Philadelphia shoulder a rising burden of local welfare payments and remain a viable economic center? Table 7 illustrates just how fragile Philadelphia's private economy is to any policy which increases taxes without compensating mobile firms and households with better public services; decentralization of welfare spending is such a policy. Increasing the city's responsibility for dependent household transfers from its current share $(\psi)$ of .095 to .25 will shrink both the city's private and public economies by about 15 percent. If ever asked to assume primary $(\psi \geq .85)$ responsibility for its poor, Philadelphia will not survive as an economic city.

Two extensions of our model seem particularly valuable. First, the new economic geography is finding increasing evidence for the importance of agglomeration economies, both in the production (Cíccone and Hall, 1996) and household sectors (Glaeser, 2000). Our model can accommodate such extensions in a relatively straightforward manner by allowing aggregate firm capital or total employment to influence individual firm efficiency and by allowing total residents or city demographics to affect individual household utility. How agglomeration

simulations of city revenues. The equilibrium revenue effects of introducing such subsidies are not obvious, however. Allowing a subsidy for firm capital will lower property tax revenues from firms, but to the extent it attracts jobs and residents to the city there will be offsetting effects through higher residential property taxes and higher wage, sales, and gross receipts tax revenues. 
economies affect the size and responsiveness of the private economy to changes in fiscal policies remains an open question. Second, the analysis here is static, yet perhaps the most interesting question today, particularly for developing economies, is how cities influence economic growth. There is strong evidence that cities serve as important centers for production efficiency and knowledge spillovers, both crucial to national growth; see Black and Henderson (1999). Yet as we have seen here, local fiscal policies have important effects on city size and on the composition of the city's labor force. Adding local fiscal policy to models of city size and city growth seems to us the important next steps in our understanding of fiscal policies in open economies. 


\section{REFERENCES}

Arnott, R. and J. MacKinnon (1977), "The Effects of the Property Tax: A General Equilibrium Simulation," Joumal of Urban Economics, 4, pp. 389-407.

Baicker, K. (1999), "Government Decision-Making and the Incidence of Federal Mandates," mimeo. Darmouth College.

Bartik, T. (1991), Who Benefits from State and Local Economic Development Policies?, Upjohn Institute, Kalamazoo, MI.

Black, D. and V. Henderson (1999), "A Theory of Urban Growth," Joumal of Political Economy, 107, pp. 252-284.

Brueckner, J. (1981), "Labor Mobility and the Incidence of the Residential Property Tax," Joumal of Urban Economics, 10, pp. 173-182.

Ciccone, A. and R. Hall (1996), "Productivity and the Density of Economic Activity," American Economic Review, 86, pp. 54-70.

Epple, D. and T. Romer (1991), "Mobility and Redistribution," Joumal of Political Economy, 99, pp. 828-858.

Fallon, P. R. and P. R. G. Layard (1975), "Capital-Skill Complementarity, Income Distribution, and Output Accounting," Joumal of Political Economy, 83, pp. 279-301.

Glaeser, E. (2000), "The Future of Urban Research: Non-Market Interactions," Brookings Wharton Papers on Urban Affairs, 1, (forthcoming).

Goolsbee, A. (1999), "In a World Without Borders: The Impact of Taxes on Internet Commerce," NBER WP. No. 6863, Cambridge, MA: pp. 1-29.

Gyourko, J. and R. Voith (2000), "The Price Elasticity of Demand for Residential Land," mimeo, Wharton School, University of Pennsylvania.

Haughwout, A. (1998), "Aggregate Production Functions, Interregional Equilibrium, and the Measurement of Infrastructure Productivity," Joumal of Urban Economics, 44, pp. 216227.

Haughwout, A. (2000), "Public Infrastructure Investments, Productivity, and Welfare in Fixed Geographic Areas," mimeo., Federal Reserve Bank of New York.

Haughwout A., R. P. Inman, S. Craig, and T. Luce (2000), "Local Revenue Hills: A General Equilibrium Specification with Evidence from Four U.S. Cities," NBER WP 7603. 
Inman, R. P. (1979), "The Fiscal Performance of Local Governments: An Interpretative Review," in P. Mieszkowski and M. Straszheim (eds.), Current Issues in Urban Economics, The Johns Hopkins University Press, pp. 270-321.

Inman, R. P. (1989), "The Local Decision to Tax: Evidence from Large U.S. Cities," Regional Science and Urban Economics, 19, pp. 455-491.

Inman, R. P. and G. Ritter (1999), "Local Taxes and the Economic Future of Philadelphia," Greater Philadelphia Regional Review, Winter, pp. 5-8.

Judd, K. (1999), "Optimal Taxation and Spending in General Competitive Growth Models," Journal of Public Economics, 71, pp. 1-26.

Krusell, P., L. E. Ohanian, J. V. Rios-Rull, G. L. Violante (1998), "Capital-Skill Complementarity and Inequality: A Macroeconomic Analysis," mimeo., University of Pennsylvania.

Meyer, B. D. (1999), "Do the Poor Move to Receive Higher Welfare Benefits?" mimeo., Northwestern University.

Mieszkowski, P. (1972), "The Property Tax: An Excise or Profits Tax?" Journal of Public Economics, 1, pp. 73-96.

Minzz, J. and H. Tulkens (1986), "Commodity Tax Competition Between Member States of a Federation: Equilibrium and Efficiency," Joumal of Public Economics, 29, pp. 133-172.

Pasha, H. A. and A. F. A. Ghaus (1995), "General Equilibrium Effects of Local Taxes," Journal of Urban Economics, 38, pp. 253-271.

Polinsky, M. and D. Rubinfeld (1978), "The Long-run Effects of a Residential Property Tax and Local Public Services," Journal of Urban Economics, 5, pp. 241-262.

-Poterba, J. (1989), "Tax Reform and the Market for Tax-Exempt Debt," Regional Science and Urban Economics, 19, pp. 537-562.

Roback, J. (1982), "Wages, Rents, and the Quality of Life," Joumal of Political Economy, 90, pp. 1257-1278.

Rosen, S. (1979), "Wage-based Indexes and the Quality of Life," in P. Mieszkowski and M. Straszheim (eds.), Current Issues in Urban Economics, Baltimore: Johns Hopkins University Press,."pp. 74-104.

Sullivan, A. (1985), "The General Equilibrium Effects of the Residential Property Tax: Incidence and Excess Burden," Journal of Urban Economics, 18, pp. 235-250. 
Summers, A. and L. Jakubowski (1997), "The Fiscal Burden of Unreimbursed Poverty Expenditures," Greater Philadelphia Regional Review, Spring/Summer, pp. 10-12.

Summers, L. (1981), "Capital Taxation and Accumulation in a Life Cycle Growth Model," American Economic Review, 71, pp. 533-544.

Walsh, M. and J. Jones (1988), "More Evidence on the "Border Tax" Effect: The Case of West Virginia, 1979-1984," National Tax Joumal, 41, pp. 261-266.

Wildasin, D. (1986), Urban Public Finance, Harwood.

Wilson, J. D. (1986), "A Theory of Interregional Tax Competition," Joumal of Urban Economics, 19, pp. 296-315.

Wilson, J. D. (1999), "Theories of Tax Competition," National Tax Journal, 52, 269-304.

Zodrow, G. and P. Mieszkowski (1986), "Pigou, Tiebout, Property Taxation and the Underprovision of Local Public Goods," Journal of Urban Economics, 19, pp. 356-370. 